\title{
Micro RNAs Promoting Growth and Metastasis in Preclinical In Vivo Models of Subcutaneous Melanoma
}

\author{
ULRICH H. WEIDLE, SIMON AUSLÄNDER and ULRICH BRINKMANN
}

Roche Pharma Research and Early Development (pRED), Large Molecule Research, Roche Innovation Center Munich, Penzberg, Germany

\begin{abstract}
During the last years a considerable therapeutic progress in melanoma patients with the RAF V600E mutation via RAF/MEK pathway inhibition and immunotherapeutic modalities has been witnessed. However, the majority of patients relapse after therapy. Therefore, a deeper understanding of the pathways driving oncogenicity and metastasis of melanoma is of paramount importance. In this review, we summarize microRNAs modulating tumor growth, metastasis, or both, in preclinical melanoma-related in vivo models and possible clinical impact in melanoma patients as modalities and targets for treatment of melanoma. We have identified miR-199a (ApoE, DNAJ4), miR-7-5p (RelA), miR-98a (IL6), miR-219-5p (BCL2) and miR-365 (NRP1) as possible targets to be scrutinized in further target validation studies.
\end{abstract}

In 2018, 96,000 patients were diagnosed with melanoma in the US with a death toll of about 7,000 due to metastatic disease (1). Cutaneous-, mucosal- and ocular melanoma have been identified as major subtypes of melanoma (2). In this review, we focus on cutaneous melanoma with superficial spreading melanoma, nodular melanoma, lentigo maligna and acral melanoma as major subtypes (2). Oncogenic mutations have been identified in v-raf murine sarcoma viral oncogene homolog B1 (BRAF), cyclin-dependent kinase inhibitor 2A

This article is freely accessible online.

Correspondence to: Ulrich H. Weidle and Ulrich Brinkmann, Roche Innovation Center Munich, Roche Diagnostics GmbH, Nonnenwald 2, D-82372 Penzberg, Germany. Tel: +49 8856604753, e-mail: weidle49@t-online.de (UHW), ulrich.brinkmann@roche.com (UB)

Key Words: Epithelial-mesenchymal transition, metastasis models, microRNA editing, microRNA inhibition and reconstitution of function, migration, invasion and proliferation, therapeutic targets, review.
(CDKN2A), NRAS and p53 (3). Approximately 50\% of melanomas harbor mutations in BRAF leading to aberrant activation of the mitogen-activated protein kinase (MAPK) signaling pathway (4). Clinical therapeutics for advanced-stage melanoma have improved dramatically with the development of V600E-BRAF and mitogenactivated protein kinase (MEK) inhibitors, immune checkpoint blocking antibodies and a modified oncolytic herpes virus, as approved therapeutic agents (5). Early clinical trials point to further clinical benefit by triple combinations of V600E-specific BRAF inhibitors, MEK inhibitors and immune checkpoint inhibitors (6-8). However, relapse due to drug resistance is observed in the vast majority of patients. Phenotype plasticity and interactions of transformed melanocytes with the tumor microenvironment are resistance-promoting factors (9, 10). In order to identify new targets and modalities for therapeutic intervention in melanoma we reviewed the role of microRNAs (miRs) in the context of growth and metastasis of this disease. We focused on miRs for which efficacy in preclinical in vivo models has been shown, as mediators of tumor growth (TG), metastasis or both.

\section{Metastasis of Melanoma}

Melanoma preferentially metastasizes through the lymphatic route, but in a minority of cases dissemination through the haematogenous route has been observed (11). Before metastasis, melanoma cells extend to the adjacent epidermis and undergo epithelial-mesenchymal transition (EMT) $(12,13)$. The following metastatic cascade includes steps such as intravasation, circulation as single cells or cell clusters coated with platelets, arrest in capillaries at a distant site, extravasation into the parenchyma of distant organs, formation of indolent micrometastases in supportive niches and finally activation of the dormant cells and colonisation of the respective target organs (14). Melanoma can colonize 
different organ sites either sequentially or synchronously (15-17). Major target organs of metastasis of subcutaneous melanoma are the lungs, brain, liver and bones $(16,17)$. A total of $40-50 \%$ of patients with stage IV melanoma develop brain metastases (17). The lungs are the most frequent target organs of metastasis in patients with advanced subcutaneous melanoma (16). In contrast, uveal melanoma almost exclusively relapses to the liver, supporting the concept of compatibility of metastatic cells with host stroma (18). Once several metastases have formed, cells from each metastasis seed and reseed other tumors adding considerable complexity to the diversity of metastatic clones (14).

\section{microRNAs and Their Role in Oncology}

miRs are small RNAs with a length in the range of 22 nucleotides (nts) that direct post-transcriptional repression of target mRNA transcripts (19). Knock-out experiments have revealed important biological functions for many miRs (19). They are transcribed by polymerase II and approximately 1,900 miRs have been identified in humans $(20,21)$. Corresponding miR genes can be localized in exons, introns or intergenic regions $(22,23)$. In the canonical pathway, they are synthesized in the nucleus as pri-miRNAs containing a hairpin loop, processed by a micropocessor (DROSHA, DGCR8) to pre-miR hairpin structures and subsequently exported to the cytoplasm by exportin $5(24,25)$. In the cytoplasm, pre-miRs are cleaved by DICER to produce a 20 nucleotides (nts) miR duplex with $5^{\prime}$ phosphate and a two nts overhang at each end. One strand of the miR duplex is loaded into the guide-strand channel of an Argonaute protein to form a silencing complex, whereas the passenger strand is discarded $(24,25)$. Within the silencing complex miR seed sequence, nts 2-7 are poised to initially interact with target mRNAs. If pairing is very extensive, the target can be sliced, if not, translation is inhibited $(24,25)$. One type of miR can target several distinct mRNAs and a single mRNA can be cleaved by several different types of miRs, thus enabling interference with several cancer-related networks with the potential of rewiring the transformed and metastatic state (26). The role of miRs in oncology was identified in the context of pathogenesis of B-cell chronic lymphatic leukemia (B-CLL). It was found that the genomic loci of miR-15a and miR-16-1 are deleted in the majority of patients with this disease $(27,28)$. These miRs are involved in the cleavage of the anti-apoptotic protein B cell lymphoma 2 (BCL2) and deletion of these miRs recapitulates the human disease phenotype in mice (29). In addition to oncogenesis, miRs are involved in metastasis of different types of cancer. We recently summarized the role of miRs in metastasis of breast-, prostate, non-small cell lung carcinoma and ovarian cancer (30-33).

\section{miRs Involved in Growth of Melanoma Cells With In Vivo Activity in Preclinical Models}

Up-regulated miRs promoting melanoma growth in preclinical in vivo models. The expression level of miRs-221 and -222 (Figure 1) correlates with melanoma progression (34). Antagomirs against miR-221 and -222 inhibit invasion and foci formation of Mel 665/1 melanoma cells and intratumoral bolus injection of antagomirs inhibits TG in nude mice (34). Tyrosine-protein kinase KIT (c-KIT receptor) and p27 Kip/cyclin-dependent kinase inhibitor $1 \mathrm{~B}$ (CDKN1B) have been identified as targets of miR-221 and -222 (34). c-KIT receptor regulates melanogenesis, cell growth, migration and survival (35). During progression of melanoma, loss of c-KIT is a crucial event due to prevention of stem cell factor/c-KIT triggered apoptosis (36). CDKN1B inhibits cell cycle progression of melanoma cells by binding to cyclin-dependent kinase (CDK)/cyclin complexes (37). miR-378 (Figure 1) is up-regulated during progression of melanoma and potentiates migration, invasion and EMT in A375 and A875 melanoma cells (38). miR-378 promotes TG of A875 melanoma cells in vivo (38). It targets tumor suppressor forkhead box N3 (FOXN3), a member of the forkhead box (FOX) family which act as a tumor suppressor (TS) $(39,40)$. FOXN3 also interacts with $ß$-catenin to promote down-regulation of wingless-type (WNT)/ß-catenin signaling proteins (38).

Down-regulated miRs inhibiting melanoma growth in preclinical in vivo models. miR-219-5p (Figure 1) is downregulated in melanoma and correlates with unfavorable prognosis (39). Up-regulation of miR-219-5p in A375 melanoma cells with a transfected miR-mimetic inhibits proliferation, invasion and enhances apoptosis (39). A375 cells transfected with a miR-mimetic show decreased growth after subcutaneous implantation into the flanks of nude mice (39). BCL2 was identified as a direct target of miR-219-5p (39-42).

Low expression of miR-612 (Figure 1) was significantly associated with shorter overall and disease-free survival in melanoma patients (43). miR-612 suppresses growth, migration and invasion of SK-MEL-28 and A375 melanoma cells (43). A375 cells transfected with miR-612 grow significantly slower than control cells after subcutaneous implantation in nude mice. Espin, an actin binding protein, was identified as a direct target of miR-612. Espin is involved in actin cytoskeleton remodeling thus affecting cell growth, migration and invasion $(44,45)$.

Up-regulated miRs mediating metastasis in preclinical in vivo melanoma-related models. miRs-30b and -30d (Figure 2 ) have redundant function and their expression marks the progression from primary to metastatic melanoma (46). 


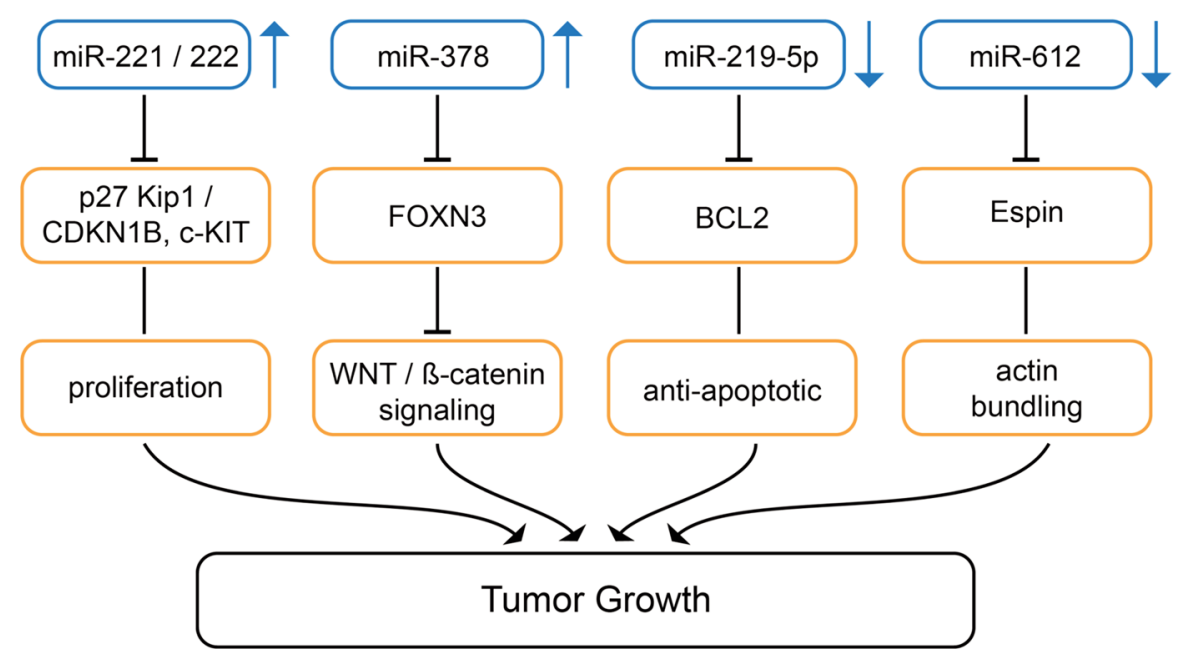

Figure 1. miRs mediating tumor growth in melanoma-related preclinical in vivo models. miRs-221/-222 and miR-378 are up-regulated, miR-219-5p and miR-612 are down-regulated in melanoma in comparison to corresponding normal tissues. Arrows indicate up- or down-regulation. BCL2: Bcell lymphoma 2; c-KIT: tyrosine-protein kinase KIT; FOXN3: Forkheadbox N3; p27 Kip1/CDKN1B: cyclin-dependent kinase inhibitor 1B, WNT: wingless-type.

Genomic amplification of miR-30b/d has been observed in a subset of melanoma patients (46). In melanoma cells $4 \mathrm{~L}$ and 5B1, miRs-30b/d stimulate invasive capacity without affecting proliferation (46). Overexpression of miR-30b/d in B16F10 melanoma cells enhances lung metastases after tail vein injection (46). Inoculation of $5 \mathrm{~B} 1$ cells transduced with miR-30d into the flanks of mice enhances local muscle invasion and metastasis to the lungs and the liver (46). miR30d triggers infiltration of regulatory T-cells (Tregs) to the metastatic site mediated by interleukin 10 (IL10) (46). Nacetylgalactosaminyltransferase 7 (GALNT7) has been identified as a direct target of miR-30b/d (46). GALNT7 initiates mucin O-linked glycosylation in the Golgi apparatus by catalyzing transfer of $\mathrm{N}$-acetylgalactosamine to Ser and Thr on target proteins (47). GALNT7 affects the structure of multiple transmembranes substrates determining their interaction with the extracellular microenvironment (47). Inactivation of GALNT7 has been shown to promote metastasis (46).

Expression of miR-182 (Figure 2) increases with progression from primary to metastatic melanoma (48). miR182 stimulates cell migration and invasion of A375 and SKMEL19 melanoma cells, whereas silencing of miR-182 triggers cell death (48). B16F10 cells transduced with miR182 give rise to increased lung metastases after tail vein injection (48). Forkhead box 03 (FOXO3) and microphtalamia-associated transcription factor (MITF) have been identified as direct targets of miR-182 (48). FOXO3 functions as a tumor suppressor (TS) controling numerous regulators of the cell cycle and apoptosis such as proapoptotic BIM, a member of the BCL2 family (49-51). MITF is a basic helix-loop-helix leucine zipper transcription factor which controls lineage-specific pathway regulation in many cell types including melanocytes, osteoclasts and mast cells $(52,53)$. MITF represses proliferation by activating cell cycle inhibitors such as p16 ${ }^{\mathrm{INK} 4 \mathrm{a}}$ which inhibits CDK4 and p21-CDK-interacting protein 1 (p21cip1) and controls cell migration by regulating the formin diaphanous 1 (DIA1) which controls cell migration. DIA1 is a RAS homologue (RHO)-GTPases effector and is involved in polymerization of actin and coordination of cytoskeleton and microtubule networks at the cell periphery $(54,55)$.

miRs-199-3p, -199-5p and -1908 (Figure 2) promote invasion in MeWo-LM2 and A375 melanoma cells as well as endothelial recruitment and angiogenesis (56). Their overexpression in the poorly metastatic MeWo cells causes colonization of the lungs more efficiently than their parental populations (56). Apolipoprotein E (ApoE) and DNA J heat shock factor protein family (Hsp40) member A4 (DNAJ4) have been identified as direct targets of miRs 199-3p, -199$5 p$ and -1908 (56). ApoE targets low density receptor related protein 1 (LRP1) on melanoma cells and LRP8 on endothelial cells to suppress invasion of melanoma cells and migration of endothelial cells (56-60). Heat shock proteins, such as DNAJ4 have been shown to be involved in proliferation, differentiation and carcinogenesis (61).

miR-200c (Figure 2) was shown to target SEC 23 homolog A (SEC23A) (62). SEC23A interacts with components involved in anterograde versicle transport from the endoplasmic reticulum to the Golgi apparatus (63). 


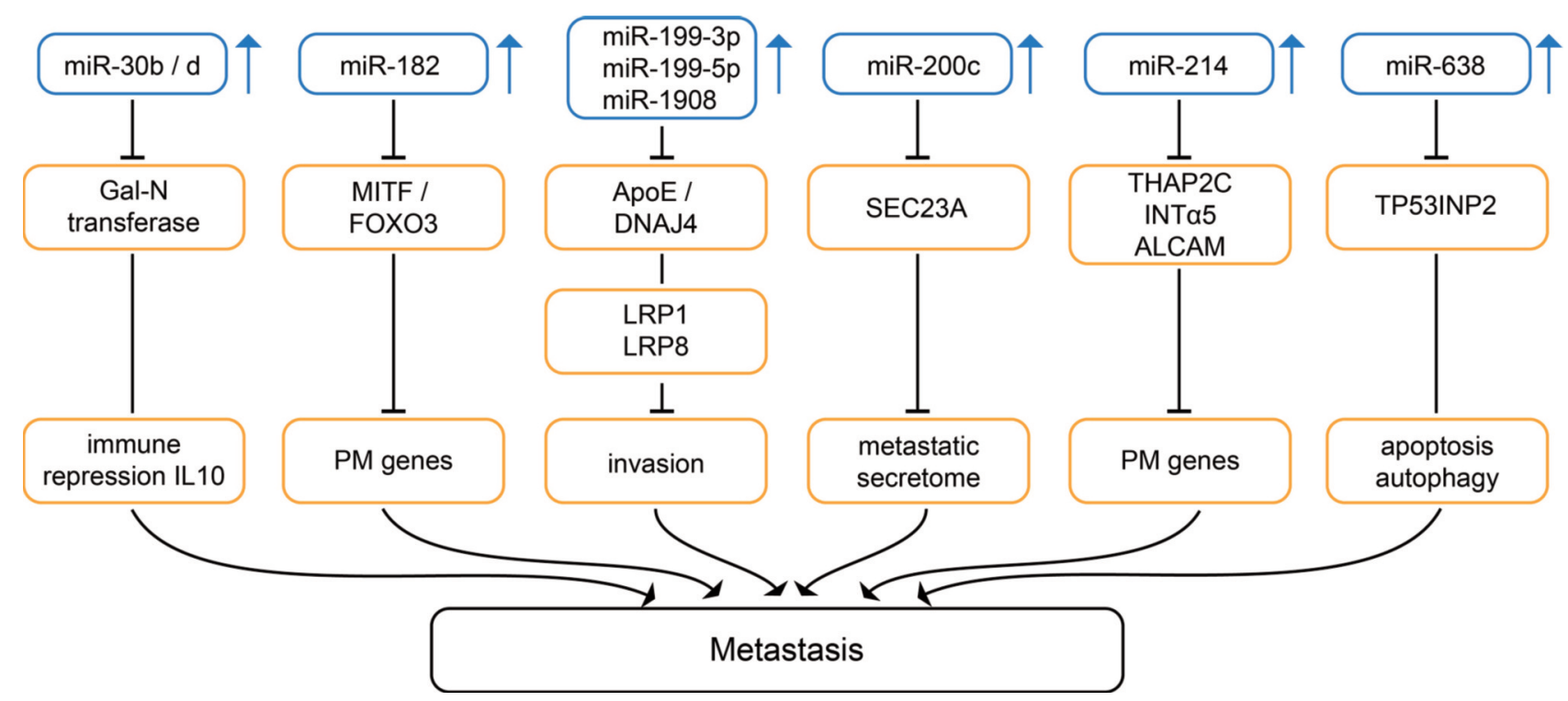

Figure 2. Up-regulated miRs mediating metastasis in melanoma-related in vivo models. Upward arrows indicate up-regulation of the corresponding miRs in melanoma versus corresponding normal tissues. ALCAM: Activated leukocyte cell adhesion molecule; Apo E: apolipoprotein E; DNAJ4: DNAJ heat shock protein family member A4; FOXO3: forkhead box O3; IL10: interleukin 10; INTa5: integrin a5; LRP1,8: low density lipoproteinrelated protein 1 or 8; PM: pro-metastatic; SEC23A: SEC23 homolog A; TFAP2C: transcription factor AP2 $\gamma$; TP53INP2: tumor protein p53inducible nuclear protein 2.

Overexpression of miR-200c and SEC23A interference accelerate oligometastatic to polymetastatic progression of human melanoma cell line M14 after tail vein injection (63). The metastasis promoting activity of miR-200 is dependent on selective reprogramming of the secretome by depletion of SEC23A (62, 64). As identifed by mass spectrometry, different proteins such as thrombospondin (65), transferrin (66), vitamin D binding protein (67), C-X-C chemokine receptor 4 (CXCR4) (68) and S100 calcium-binding protein A8 (S100A8) (69) may be involved in promoting metastasis by $\mathrm{miR}-200 \mathrm{c}$.

miR-214 (Figure 2) expression in A375P melanoma cells enhances in vitro cell movement and improves cell adhesion to fibronectin, laminin and collagen (70). MA2 melanoma cells overexpressing miR-214 give rise to higher numbers of lung metastases in comparison to the control cell line after tail vein injection in severe combined immuno-deficicent (SCID) mice (70). Transcription factor AP2C (TFAP2C) has been identified as a direct target of miR-214 (70). Subsequent investigations have shown that depletion of mi214 blocks dissemination of melanoma cells by repressing passage of melanoma cells through the blood endothelium by reducing the cell adhesion molecules integrin $\alpha 5$ (INT $\alpha 5)$ and activated leukocyte adhesion molecule (ALCAM) (7173). miR-214 affects TFAP2C directly and TFAP $2 A$ indirectly (74). These transcription factors play a role in regulating expression of genes in involved in invasion, extravasation and angiogenesis such as human epidermal growth factor receptor 2 (HER2) (proliferation), p21 (cellcycle), c-KIT (TS), BCL2 (apoptosis), cluster of differentiation CD95 (CD95) (apoptosis), melanoma cell adhesion molecule (MCAM), mucin 18 (MUC18) and Ecadherin (adhesion), matrix metalloproteinase 2 (MMP2) (invasion), metastasis suppressor KAI-1 (invasion) and vascular endothelial growth factor (VEGF) as well as thrombin receptor (angiogenesis) $(74,75)$. Especially, the role of ALCAM in melanoma progression is well documented $(76,77)$. Therapeutic silencing of miR-214 has been shown to inhibit tumor progression in multiple mouse models (78).

miR-638 (Figure 2) is strongly up-regulated during melanoma progression (79). Transfection of miR-638 into SK-Mel-147 and SK-Mel-28 cells results in increased invasion (79). SK-Mel-147 overexpressing miR-638 show more metastatic nodules in the lungs after tail vein injection into NOD scid IL2R gamma chain knockout mice (NSG) in comparison to the control cell line (79). Knockdown of miR638 induces p53-mediated apoptosis and autophagy in melanoma cells (79). p53 interacting protein 2 (TP53INP2) was identified as a direct target of miR-638 (79). TP53INP2 plays an important role as a TS through interaction with $\mathrm{p} 53$ $(80,81)$. 
A

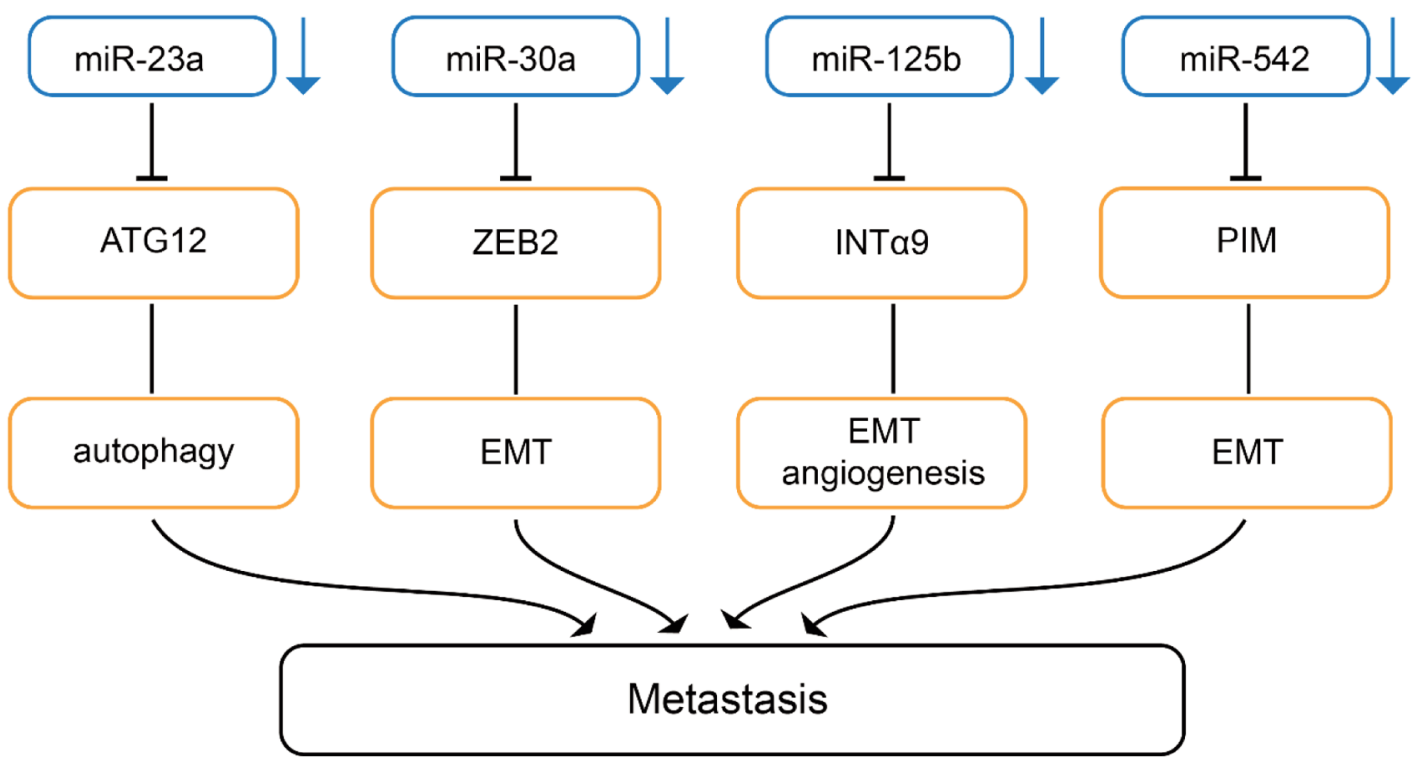

B

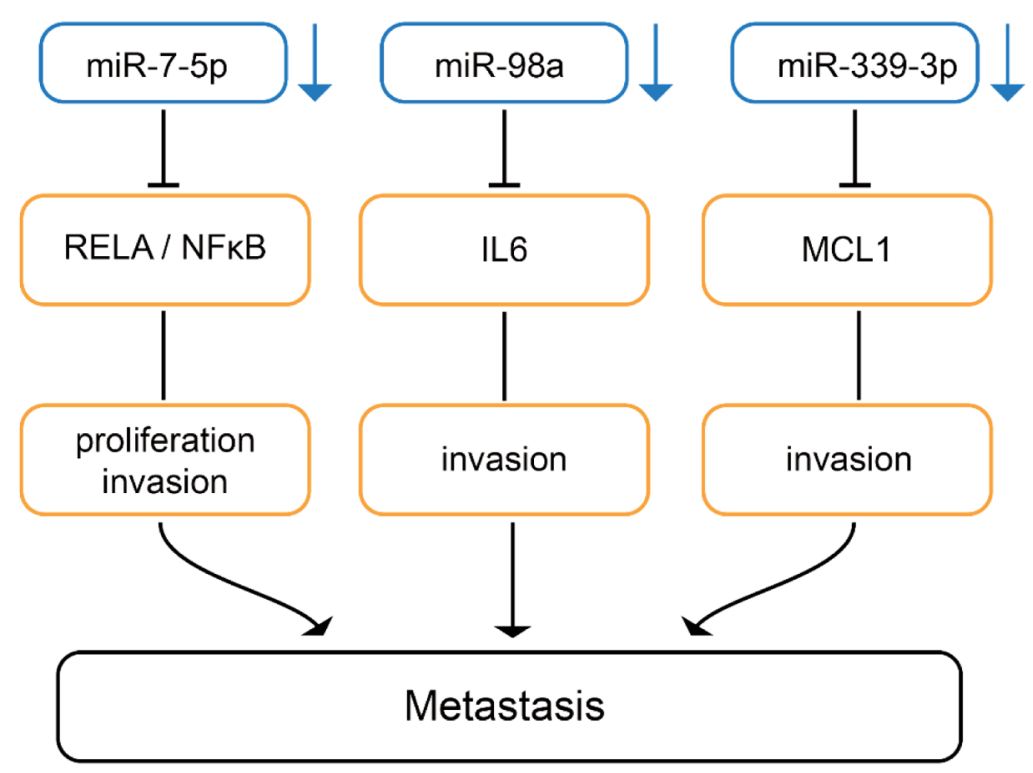

Figure 3. Down-regulated miRs inhibiting metastasis in melanoma-related in vivo models. Downward arrows indicate down-regulation in melanoma compared to matching normal tissues. (A) miRs inhibiting metastases by attenuating autophagy, epithelial-mesenchymal transition and miR-editing. ATG 12: Autophagy related 12; EMT: epithelial mesenchymal transition; INTa9: integrin a9; PIM-1: serine/threonine-protein kinase PIM-1. (B) miRs inhibiting metastasis by interfering with signal-transduction pathways. IL6: Interleukin 6; MCL-1: induced myeloid leukemia cell differentiation protein; $N F k B$ : nuclear factor $k B$; Rel A: v-rel avian reticuloendotheliosis viral homolog $A$.

Down-regulated miRs Inhibiting Metastasis in Preclinical Melanoma-related In Vivo Models

Down-regulated miRs inhibiting epithelial mesenchymal transition. Serum miR-23a (Figure 3A) has been identified as a potential biomarker for predicting melanoma metastasis and prognosis (82). Overexpression of miR-23a inhibits invasion, migration and epithelial mesenchymal transition (EMT) of A2058 and A375 melanoma cells (82). Subcutaneously implanted A2058 melanoma cells transduced with miR-23a give rise to decreased metastases in the lungs and the liver in nude mice without affecting TG (82). miR-23a down- 
regulation results from up-regulation of the runt-related transcription factor 2 (RUNX2) in melanoma $(82,83)$. Autophagy-related 12 (ATG12) has been identifed as a direct target of miR-23a (82). ATG12 is essential for autophagy and promotes apoptosis through interaction with anti-apoptotic members of the BCL2 family $(84,85)$. The miR-23-ATG12 axis suppresses melanoma invasion and migration through the AMP activated kinase (AMPK)/RHO A pathway (82). AMPK is a sensor for cellular energy and can be activated through depletion of ATP levels in cells with autophagy and exhibits anti-metastatic potential in melanoma (86). AMPK activates RHO GTPase family member A (RHO A) which mediates cytoskeletal organization by activation of RHO-associated kinases (ROCK)-myosin phosphatase target subunit 1(MYPT1) pathway during melanoma cell migration. MYPT1 is a regulatory subunit of protein phosphatase $1(82,87,88)$.

miR-30a (Figure 3A) suppresses EMT and lung metastasis of B16F10 transduced cells after tail vein injection (89). Zinc finger E-box binding homeobox 2 (ZEB2) has been identified as a direct target of miR-30a (89). ZEB2 binds to the E-cadherin promoter, resulting in down-regulation of promoter activity (90). Therefore, miR-30a increases Ecadherin expression and inhibits EMT (91). In addition to melanoma, miR-30a has been shown to be down-regulated and to inhibit EMT in non-small cell lung carcinoma (92).

miR-125b (Figure 3A) expression is decreased in melanoma tissues (93). miR-125b inhibits EMT in Mel Im and Mel Ju melanoma cells (93). Mel Im transfected with miR-125 expression constructs exhibt reduced lung metastasis after tail vein injection in nude mice (93). Integrin $\alpha 9$ (INT $\alpha 9$ ) was identified as a direct target of miR-125b (93). Knockdown of INT $\alpha 9$ expression phenocopies the effect of miR-125b overexpression in melanoma cells (93). It has been shown that INT $\alpha 9$ can promote melanoma metastasis by potentiating EMT (94).

miR-542 (Figure 3A) is down-regulated in melanoma cell lines and tissues (95). miR-542 inhibits EMT, cell division and migration of melanoma cells as well as lung metastasis after tail vein injection of miR-542-transfected melanoma cells (95). Proviral integration site for Moloney murine leukemia virus-1 (PIM-1), a serine-threonine kinase, has been identified as a direct target of miR-542 (93). PIM-1 controls EMT, cell motility, cell survival and is involved in cell metabolism (96). PIM-1 is an important target for oncology drug discovery (97).

Down-regulated miRs interfering with signaling. miR-7-5p (Figure 3B) inhibits migration and invasion of $1205 \mathrm{Lu}$ melanoma cells and lung metastasis in Nod Scid Gamma (NSG) mice after tail vein injection (98). miR-7-5p inhibits migration of $1205 \mathrm{Lu}$ and WM266-4 melanoma cells (98). Tail vein injection of $1205 \mathrm{Lu}$ cells transduced with miR-7$5 \mathrm{p}$ results in decreased lung metastases in NSG mice (98).
Nuclear factor $\mathrm{kB}$ (NFkB) p65 subunit v-rel avian reticuloendotheliosis viral homolog $\mathrm{A}(\mathrm{RelA})$ has been identified as a direct target of miR-7-5p (98-100). miR-7-5p suppresses canonical nuclear factor $\mathrm{kB}(\mathrm{NFkB})$ genes such as IL-1 $\beta,-6$ and -8 and the effects of miR-7-5p on cell cycle, invasion and migration were recapitulated by RelA knockdown (98). RelA overexpression and low miR-7-5p levels are indicators of poor prognosis in melanoma (98).

Decreased expression of miR-98a (Figure 3B) is associated with lower overall survival in melanoma patients (101). B16F1 cells transduced with miR-98 exhibit reduced migration in vitro and decreased lung metastasis after tail vein injection (101). IL6 which promotes melanoma metastasis in vitro and in vivo has been identified as a direct target of miR98 (101). IL6/IL6 receptor interaction via autocrine or paracrine loops plays an important role in tumor progression $(102,103)$. In patients with melanoma, serum levels of IL6 have been correlated with worse prognosis (104).

miR-339-3p (Figure 3B) was identified in the context of a screening program for migration-accelerating or -inhibiting miRs (105). miR-339-3p inhibits invasion of A375 melanoma cells and five other melanoma cells derived from WM and MaMel cells (105). miR-339-3p transduced A375 cells exhibit reduced lung metastasis after tail vein injection in nude mice (105). Induced myeloid leukemia cell differentiation protein (MCL-1) was identified as a direct target of miR-339 (105). MCL-1 belongs to the BCL2 family of proteins and is required for the resistance of melanoma to anoikis (106). Overexpression of MCL-1 confers resistance to BRAF V600E inhibitors alone and in combination with mitogen-activated protein kinase 1/2 (MEK1/2) inhibitors in melanoma patients (107). Several programs for preclincial and clinical evaluation of MCL-1 inhibitors are presently ongoing $(108,109)$.

\section{Up-regulated miRs Promoting Growth and Metastasis in Preclinical Melanoma-related In Vivo Models}

Knock-down of miR-21 (Figure 4A) in B16 melanoma cells inhibits cell proliferation and invasion, whereas apoptosis is promoted (110). Syngeneic mice injected with B16 cells into the tail vein exhibit large nodules in the lungs, whereas mice injected with miR-21 knock-down B16 cells give rise to only minor metastatic deposits (110). As direct targets of miR-21 TS genes phosphatase and tensin homolog (PTEN) and programmed cell death protein 4 (PDCD4) as well as antiproliferative protein B-cell translocation gene 2 (BTG2) were identified (110). PTEN has phosphatase-dependent and phosphatase-independent (scaffold) activities regulating genome stability, migration and proliferation, cell survival and metabolism (111). PDCD4 inhibits proliferation, invasion and metastasis and induces apoptosis by binding to the translation initiation factor eIF4a, several transcription factors and other 


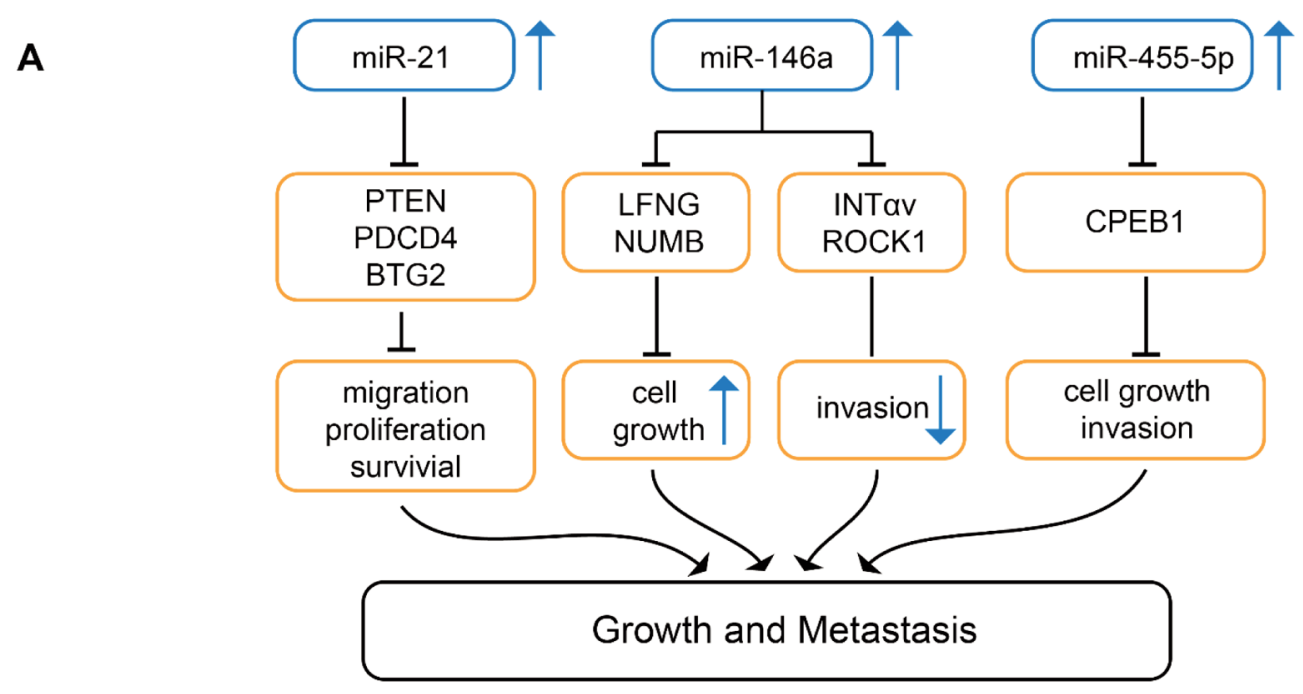

B

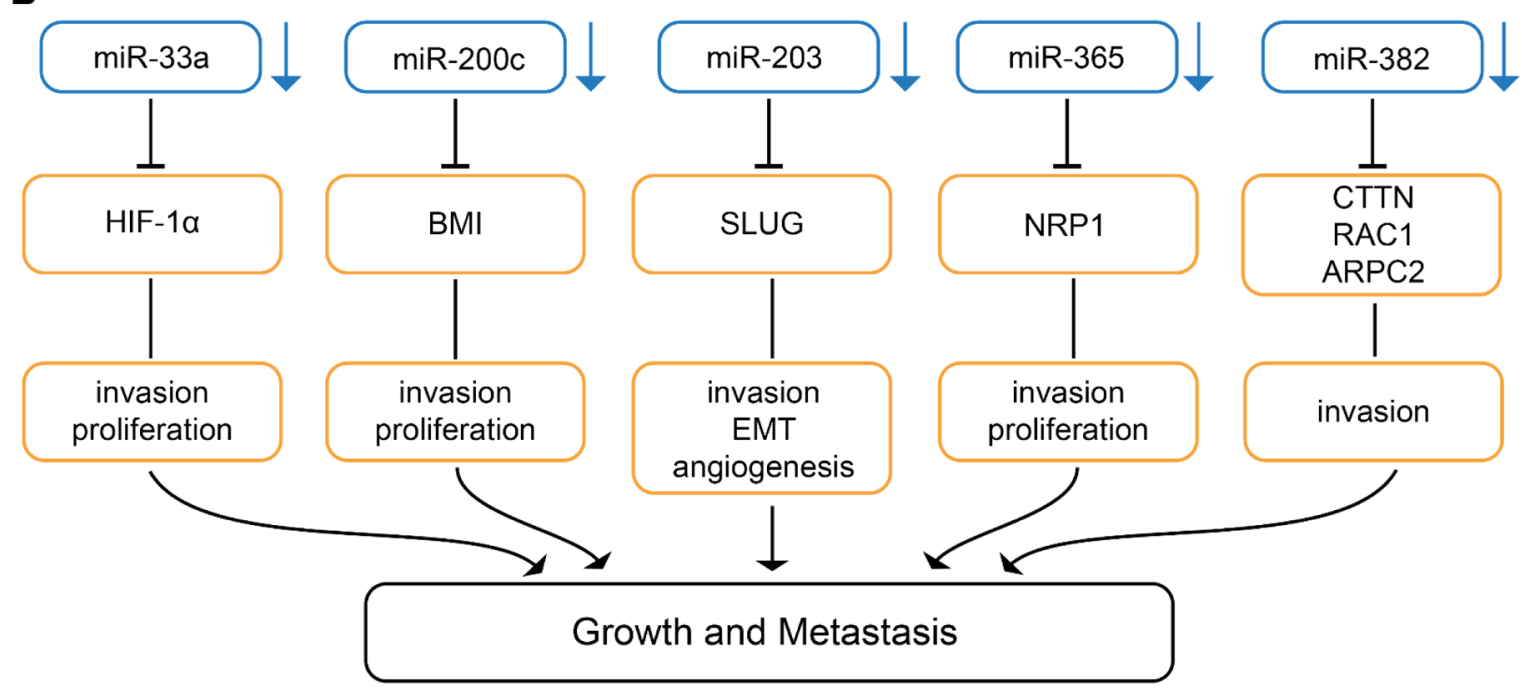

Figure 4. miRs involved in growth and metastasis in melanoma-related preclinical in vivo models. Upward arrows indicate up-regulation, downward arrows indicate down-regulation in melanoma compared to corresponding normal tissues. (A) miRs up-regulated in melanoma in comparison to corresponding normal tissues. BTG2: BTG2 family member 2; CPEB1: cytoplasmic polyadenylation element binding protein 1; INTav: integrin av; LFNG: lunatic fringe; NUMB: protein numb homolog; PDCD4: programmed cell death protein 4; PTEN: phosphatase and tensin homolog; ROCK 1: Rho-associated coiled-coil containing protein kinase 1.(B) miRs down-regulated in melanoma in comparison to corresponding normal tissues. ARPC2: Actin-related protein 2/3 complex subunit 2; BMI: B-lymphoma Mo-MLV insertion region 1 homolog; CTTN: cortactin; HIF-1 $\alpha$ : hypoxia-inducible factor 1 $\alpha$; NRP-1: neuropilin 1; RAC1: ras-related C3 botulinum toxin substrate 1; SLUG: zinc finger protein SLUG.

protein and modulates the function of the binding partners (112). BTG2 is down-regulated in many types of cancers and is involved in inhibition of proliferation, DNA repair and mRNA stability $(113,114)$. In human melanoma, miR-21 is strongly expressed in comparison to naevi and nuclear miR21 and may have an impact as a prognostic biomarker (115).

miR-146a (Figure 4A) is a miR with a dual function: it can act as an onco-miR as well as a tumor-suppressive miR. It enhances TG, but inhibits metastasis (116). miR-146a is upregulated during tumor progression, but is poorly expressed in circulating tumor cells (CTC) (116). In MA-2 and MC-1 melanoma cells down-modulation of miR-146a impairs cell proliferation as well as anchorage-independent growth in soft agar. miR-146a overexpressing MA-2 cells generate bigger tumors in comparison to control cells after subcutaneous implantation (116). miR-146a inhibits extravasation and lung 
metastasis of MA-2-miR-146a overexpressing melanoma cells after tail vein injection (116). miR-146a also affects dissemination from primary tumors. Down-modulation of miR-146a enhances dissemination of tumors to the lungs after subcutaneous implantation (116). miR-146a controls TG through its direct targets lunatic fringe (LNFG) and NUMB (116). Inhibition of NUMB and deletion of LNFG have been shown to activate the NOTCH1 pathway $(117,118)$. LNFG is an O-fucose $\beta 1,3 \mathrm{~N}$-acetyl-glucosminyl transferase which glycosylates epidermal growth factor (EGF)-like repeats in the extracellular domain of NOTCH, thus inhibiting JAGGEDmediated NOTCH activation (119). NUMB is a membranebound protein which is also involved in suppression of NOTCH signaling (120). miR-146a mediated down-regulation of direct targets INT $\alpha \mathrm{v}$ and serine/threonine kinase RHOassociated, coiled-coil containing protein kinase 1 (ROCK1) affects motility, but not TG (116). ROCK1 mediates rounded cell migration, whereas INT $\alpha \mathrm{v}$ is involved in mesenchymallike invasion characterized by cell polarization and membrane protrusion (121). ROCK1 is a major effector of small GTPase RHO A and regulates the actomyosin cytoskeleton promoting contractile force generation and plays a role in mobility, metastasis and angiogenesis $(122,123)$.

Wild-type miR-455-5p (Figure 4A) promotes melanoma growth and metastases, the A-to-I edited version inhibits these properties (124). miR-455-5p is edited by adenosine deaminase acting on RNA (ADAR1) (124). ADAR1mediated RNA editing of miRs can affect their biogenesis or can change their binding sites $(125,126)$. ADAR-1 expression and the edited version of miR-455-5p decrease during melanoma progression (124). SB2 melanoma cells transduced with wild-type miR-455-5p exhibit increased TG after subcutaneous implantation into nude mice and increased incidence of experimental lung metastasis (124). Cytoplasmic polyadenylation element binding protein 1 (CPEB1) has been identified as a direct target of wild-type miR-455-5p (124). CPEB1 binds to a specific RNA sequence in the $3^{\prime}$-UTR of the corresponding mRNA referred to as cytoplasmic polyadenylation element and is involved in translational control $(127,128)$. CPEB 1 has been identified as a TS in gastric and thyroid cancer $(129,130)$. In contrast to the wild-type miR-455-5p, the edited version targets oncogenes such as integrin $\alpha 2$ (INT $\alpha 2$ ), mouse double minute 4 (MDM4) and ras homolog gene family member $\mathrm{C}$ (RHO-C) (124). The clinical relevance of these findings remains to be investigated.

\section{Down-regulated miRs Inhibiting Growth and Metastasis in Melanoma-related Preclinical In Vivo Models}

miR-33a (Figure 4B) is expressed at a low level in metastatic melanoma (131). miR-33a inhibits proliferation and invasion of human melanoma cells WM-35 and WM-451 (131). In vivo, A375 cells transduced with miR-33a showed reduced TG after subcutaneous implantation in comparison to control cells (131). Hyoxia-inducible factor- $1 \alpha(\mathrm{HIF}-1 \alpha)$ was identified as a direct target of miR-33a (131). HIF-1 $\alpha$ exacerbates conversion of normal melanocytes to melanoma (132) and promotes metastasis by activation of tyrosine kinase SRC (133). Hypoxia controls metastasis of mouse and human melanoma cells (134). HIF-1 $\alpha$ expression correlates with severity of disease and metastasis in melanoma patients (135).

miR-200c (Figure 4B) exhibits reduced expression in melanoma in comparison to naevi (136). miR-220c inhibits proliferation of melanoma cell lines WM115A, $1205 \mathrm{Lu}$, WM793, WM3523A and WM35 (136). In vivo growth in nude mice is inhibited after subcutaneous implantation into the flanks of miR-200c transduced WM115A cells in comparison to the non-transduced control cell line (136). Polycomb complex protein B lymphoma Mo-MLV insertion region 1 homolog (BMI-1) has been identified as a direct target of miR-200c (136). However, also other genes are down-regulated by miR-200c such as membrane transporters ATP-binding cassette superfamily $G$ members 2 and 5 (ABCG2, ABCG5) and multi-drug resistance protein 1 (MDR1), whereas E-cadherin is up-regulated (136). BMI-1 knockdown phenocopies miR-200c overexpression (136). BMI-1 belongs to the polycomb group of proteins, a class of transcriptional repressors that orchestrate changes in chromatin structure to regulate gene activity (136). BMI-1 functions as a transcriptional repressor of the inhibitor of CDK4A/ARF tumor suppressor (INK4A/ARF) locus. INK4A inhibits cyclin-dependent kinase 4A (CDK4) activity and blocks entry into the cell cycle $(137,138)$. The findings support the existence of an interconnected network of miR200c, BMI-1, E-cadherin and MDR-1 (136-138). In addition to cancer cell proliferation, BMI-1 is involved in invasion, metastasis, self-renewal of cancer stem cells (CSC) and their differentiation and is a promising target for cancer therapy (139). Diminished expression of miR-200c correlates with the acquisition of a stem cell-like phenotype during melanoma progression (140-142). miR-200c is downregulated in melanoma and acts as a TS (143).

miR-203 (Figure 4B) is decreased in metastatic melanoma and its expression level correlates with survival (144). miR203 suppresses motility and sphere formation of melanoma cell lines BE, SK-Mel-28 and DFB (144). In vivo, BE cells transduced with miR-203 show decreased neovascularization of their xenografts (144). Reduced lung metastases was noted after tail vein injection of miR-203 transduced BE cells (144). SLUG (SNAI2), a zinc finger protein transcriptional repressor which down-regulates Ecadherin, was identified as a direct target of miR-203 (144). SLUG is involved in EMT and exerts anti-apoptotic activity (145). In melanoma, SLUG expression is essential for 
metastasis (146). Overexpression of SLUG is associated with lymph node metastasis, post-operative relapse and shorter patient survival in lung cancer and colorectal cancer patients (147, 148).

miR-365 (Figure 4B) is down-regulated in human melanoma tissues relative to adjacent normal tissues (149). Ectopic expression of miR-365 in A375 and G361 melanoma cells attenuates cell proliferation and induces apoptosis in these cells (149). In vivo, miR-365 overexpression in A375 cells suppresses TG after subcutaneous implantation and reduces lung metastases after tail vein injection into nude mice (149). Neuropilin-1 (NRP-1) has been identified as a direct target of miR-365 (149). NRP-1 is a transmembrane glycoprotein that acts as a co-receptor for various members of the VEGF family and modulates the activity of other extracellular ligands such as transforming growth factor $\beta$ (TGF $\beta$ ), hepatocyte growth factor (HGF), fibroblast growth factor (FGF) and platelet-derived growth factor (PDGF), factors modulating angiogenesis and therefore is a potential target for treatment of melanoma (150-152).

miR-382 (Figure 4B) is decreased in more versus less aggressive primary melanomas (153). TG of melanoma cell line WM1361a is accelerated by expression of a miR-382 decoy (153). Lung metastasis is inhibited after subcutaneous implantation of 451Lu melanoma cells transfected with miR383 into the flanks of nude mice (153). As direct targets of miR-382 cytoskeleton regulators cortactin (CTTN), actinrelated protein 2 complex (ARPC2) and ras-related $\mathrm{C} 3$ botulinum substrate 1 (RAC1) have been identified (153). CTTN is a nodal point for regulation of the actin cytoskeleton, regulates lamellopodia, directs migration and matrix metalloproteinase activity $(154,155)$. ARPC2 is a core component of the ARP $2 / 3$ complex which nucleates branched actin networks (156). RAC1 is an RHO-family GTPase that regulates a diverse set of cellular processes, particularly cell motility through regulation of actin polymerization $(157,158)$.

\section{Synopsis of Identified miRs}

The identified miRs have been classified as miRs affecting TG only, metastasis only and TG as well as metastasis in preclinical in vivo efficacy models (Figures 1-4). These effects can be achieved by up-regulation or downregegulation of the corresponding miRs in melanoma in comparison to naevi or adjacent normal tissues. A major subclass of the identified miRs targets transcription factors such as RelA (miR-7-5p), ZEB2 (miR-30a), HIF-1 $\alpha$ (miR33a), MITF and FOXN3 (miR-182), TFAP2C (miR-214), SLUG (miR-365), FOXN3 (miR-378) and CPEB1 (miR455-5p). Another sub-category of the identified miRs targets mRNAs derived from cell-cycle and apoptosis-related genes such as BTG2, PDCD4 and PTEN (miR-21), BCL2 (miR- 219-5p), BMI-1 (miR-200c), CDKN1B (miR-221, -222), MCL1 (miR-339-3p) and TP53INP2 (miR-638). Another group of the identified miRs targets components of the actin or actomyosin cytoskeleton, such as ROCK1 (miR-146a), ARPC2, CTTN and RAC1 (miR-382) as well as espin (miR612). Autophagy is affected by miRs $-23 \mathrm{a}$ and -638 and miRs -30a, -203 and -542 are involved in EMT-related pathways. An interesting observation is that an A-to-I edited miR (455-5p) can have an inhibitory impact on metastasis of melanoma cells in preclinical melanoma-related in vivo models due to change in target specificity induced by the editing process. Another observation is the finding that a component of the secretory pathway (SEC23A) can modulate the metastatic secretome. miR-146a is unique since it has a different impact on TG versus metastases. It promotes TG via targeting LFNG and NUMB resulting in activation of NOTCH signaling, whereas it inhibits metastases by targeting INT $\alpha \mathrm{v}$ and ROCK1. LFNG as well as Gal-Ntransferase (miR-30b/d) are sugar-modifying enzymes, which have an impact on metastasis and on growth as well as metastasis, respectively. Interestingly, one of the identified miRs promotes metastasis through targeting of the metabolic component ApoE. To our surprise, none of the identified miRs targets components of the rapidly accelerated fibrosarcoma (RAF)/MEK signaling pathway directly.

Clinical correlations are an important issue for prioritization of identified miRs and corresponding targets for therapeutic intervention. Up- or down-regulation of several miRs in melanoma tissues in comparison to corresponding control tissues holds true for miRs-7-5p, -23a, $-30 \mathrm{~b} / \mathrm{d},-98 \mathrm{a},-125 \mathrm{~b},-182,-199 \mathrm{a},-203,-214,-219-5 \mathrm{p},-221 /-$ $222,-365,-378$ and -638 . In addition to deregulation, correlations with disease progression and corresponding survival data are available for an up-regulated and five down-regulated miRs. miR-199a (ApoE, DNAJ4) is upregulated, miRs-7-5p (RelA), miR-98a (IL6), miR-203 (SLUG), miR-219-5p (BCL2) and miR-365 (NRP-1) are down-regulated. miR-219-5p regulates TG, miR-98a and 199a are drivers of metastasis, whereas miRs-203 and -365 have a combined impact on TG and metastasis.

Therapeutic aspects. Improved treatment options for advanced and metastatic melanoma are an important medical need. For miR-related targets, inhibition of up-regulated miRs or functional reconstitution of down-regulated miRs are the options for therapeutic intervention (more details in the following chapter). Alternatively, the identified targets can be modulated with small molecules or mAbs. However, one should keep in mind that miRs, in addition to the identified and validated targets, interfere with the messages of a several other genes. For the target of miR-219-5p, BCL2, a specific inhibitor, Venetoclax, has been approved by the FDA for treatment of CLL (159). Clinical studies with 
mAb MNRP1685A, which inhibits NRP-1, are currently ongoing (160). For IL6, the target of miR-98a, several IL6inhibitory approved agents for treatment of inflammatory or myeloproliferative neoplasms are available (161). IL6inhibitory agents are presently clinically evaluated for management of the side effects of chimeric antigen receptors (CARs)-based therapies (161).

As treatment options, prophylactic treatment of melanoma metastasis is problematic due to possible severe side-effects due to chronic treatment (162). With respect to treatment of established metastases, unprecedented responses have been achieved with programmed cell death protein 1 (PD1)- and PD1-ligand (PD-1L)-inhibitory mAbs (163-165). miRs inhibiting TG (miR-219-5p) and TG as well as metastases (miRs-203, -365) are possible candidates for treatment of metastatic melanoma as single agents or in combination with other agents such as checkpoint inhibitors. Expression of the corresponding target in metastases has to be assessed case by case. miRs affecting metastasis only (miR-7-5p, -98a, -199a) should be combined with a growth-inhibitory agent to optimize their therapeutic potential. However, it should be kept in mind, that treatment of established metastases is hampered by many critical issues such as their heterogeneous composition and disabled vasculature, resulting in poor drug penetration and resistance against drugs, which have a therapeutic impact on the corresponding primary tumor $(162,166)$.

Technical aspects. As outlined, the therapeutic options of miR-related agents for treatment of advanced melanoma are inhibition of miRs or their functional reconstitution (167169). miR inhibitors are single-stranded RNAs such as locked nucleic acids (LNA), 12-25 nts complementary to the corresponding mRNA (167). miR sponges contain multiple miR-binding sites which compete with the natural mRNA target for binding to the corresponding miR (169). Lowmolecular weight drugs can affect the transcription of miRs or interfere with their secondary structure, but specificity issues associated with corresponding compounds remain to be resolved $(167,169)$. Functional reconstitution can be performed with miR mimetics, double-stranded RNAs, designed to mimic endogenous mature miRs (168). The other option is to express the corresponding miR with plasmid or virus-based expression vectors in corresponding recipient cells (168).

However, several technical issues hampering the therapeutic application of miR-related agents remain to be resolved. Issues to be tackled are: design of efficient delivery systems, serum stability and removal of the complexed nucleic acids by the reticulo-endothelial system, renal excretion, immunogenicity and immuno-modulatory effects, hybridization-dependent and -independent off-target effects, haematological and hepatic toxicity, cytokine release syndrome (CRS), extravasation, entry into the target cell and endosomal escape (170-172).
These issues have to be optimized case-by-case. Considerable progress has been achieved by improving the binding affinity, stability, pharmaco-kinetic and pharmaco-dynamic properties of miR-related agents for optimized target modulation (173175). Progress has been achieved by stabilization of miRtargeting agents with polyethylene glycole, delivery as nanoparticles and combination with specific targeting packages and shielding to ameliorate immunogenicity and the potential to induce CRS (173-177). Complexation of miRtargeting agents to cell-penetrating viral proteins to accomplish endosomal escape is another important achievement $(178,179)$.

Finally, the relationship between siRNA and miRs as therapeutic agents should be mentioned. siRNA and miRs share many similarities. Both are short duplex RNA molecules that exert gene-silencing effects at the posttranscriptional level by targeting mRNA. However, the MOA is different. siRNAs are highly specific for only one target, whereas miRs target several mRNAs with the capacity to interfere with several pathways (180).

\section{Therapeutic Landscape}

The field of miR-based therapeutics has witnessed several serious drawbacks in the past few years (181). Several clinical studies in patients with kidney disease, Hepatitis C infection and cancer were terminated due to serious side effects despite of promising efficacy data (181). Clinical evaluation of second generation of miRs with an improved side-effect profile is underway. MIRAGEN is presently running PhaseI/II clinical studies with COBOMARSEN (MRG-106), an LNA anti-miR-155, for treatment of several blood cancers such as cutaneous T-cell lymphoma, adult Tcell lymphoma and leukemia, diffuse large B-cell lymphoma and chronic lymphocytic leukemia with a very favourable side effect profile (181). A breakthrough in the field of RNArelated therapeutics is the FDA-approval of Onpattro (ALNYLAM Pharmaceuticals), an siRNA acting in the liver of patients with transerythyrin amyloidosis and neuropathy (182). The emerging importance of RNA-based therapeutics is emphasized by a recent deal between REGENERON and ALNYLAM covering 39 targets for diseases of the eye, central nervous system and liver (183).

\section{Conflicts of Interest}

SA and UB are and UHW was employed by Roche, Roche is interested in the diagnosis and therapy of cancer.

\section{Authors' Contributions}

UHW devised the concept, coordinated and compiled the information for this review. UHW, SA and UB jointly prepared the review article and its Figures. 


\section{References}

1 Miller KD, Nogueira L, Mariotto AB, Rowland JH, Yabroff KR, Alfano CM, Jemal A, Kramer JL and Siegel RL: Cancer treatment and survivorship statistics, 2019. CA Cancer J Clin Oncol 69(5): 363-385, 2019. PMID: 31184787. DOI: 10.3322/ caac. 21565

2 Das P, Deshmukh N, Badore N, Ghulaxe C and Patel P: A review article on melanoma. Pharm Sci and Res 8: 112-117, 2016.

3 Hayward NK, Wilmott JS, Waddell N, Johansson PA, Field MA, Nones K, Patch AM, Kakavand H, Alexandrov LB, Burke H, Jakrot V, Kazakoff S, Holmes O, Leonard C, Sabarinathan R, Mularoni L, Wood S, Xu Q, Waddell N, Tembe V, Pupo GM, De Paoli-Iseppi R, Vilain RE, Shang P, Lau LMS, Dagg RA, Schramm SJ, Pritchard A, DuttonRegester K, Newell F, Fitzgerald A, Shang CA, Grimmond SM, Pickett HA, Yang JY, Stretch JR, Behren A, Kefford RF, Hersey P, Long GV, Cebon J, Shackleton M, Spillane AJ, Saw RPM, López-Bigas N, Pearson JV, Thompson JF, Scolyer RA and Mann GJ: Whole-genome landscapes of major melanoma subtypes. Nature 545: 175-180, 2017. PMID: 28467829. DOI: 10.1038/nature22071

4 Liu W, Kelly JW, Trivett M, Murray WK, Dowling JP, Wolfe R, Mason G, Magee J, Angel C, Dobrovic A and McArthur GA: Distinct clinical and pathological features are associated with the BRAF T1799A(V600E)) mutation in primary melanoma. J Invest Dermatol 127: 900-905, 2007. PMID: 17159915. DOI: 10.1038/ sj.jid.5700632

5 Luke JJ, Flaherty KT, Ribas A and Long GV: Targeted agents and immunotherapies: optimizing outcomes in melanoma. Nat Rev Clin Oncol 14: 463-482, 2017. PMID: 2837478. DOI: 10.1038/nrclinonc. 2017.43

6 Sullivan RJ, Hamid O, Gonzalez R, Infante JR, Patel MR, Hodi FS, Lewis KD, Tawbi HA, Hernandez G, Wongchenko MJ, Chang Y, Roberts L, Ballinger M, Yan Y, Cha E and Hwu P: Atezolizumab plus cobimetinib and vemurafenib in BRAFmutated melanoma patients. Nat Med 25: 929-935, 2019. PMID: 31171876. DOI: 10.1038/s41591-019-0474-7

7 Ribas A, Lawrence D, Atkinson V, Agarwal S, Miller WH Jr, Carlino MS, Fisher R, Long GV, Hodi FS, Tsoi J, Grasso CS, Mookerjee B, Zhao Q, Ghori R, Moreno BH, Ibrahim N and Hamid O: Combined BRAF and MEK inhibition with PD-1 blockade immunotherapy in BRAF-mutant melanoma. Nat Med 25: 936-940, 2019. PMID: 31171879. DOI: 10.1038/s41591-0190476-5

8 Ascierto PA, Ferrucci PF, Fisher R, Del Vecchio M, Atkinson V, Schmidt H, Schachter J, Queirolo P, Long GV, Di Giacomo AM, Svane IM, Lotem M, Bar-Sela G, Couture F, Mookerjee B, Ghori R, Ibrahim N, Moreno BH and Ribas A: Dabrafenib, trametinib and pembrolizumab or placebo in BRAF-mutant melanoma. Nat Med 25: 941-946, 2019. PMID: 31171878. DOI: 10.1038/s41591019-0448-9

9 Arozarena I and Wellbrock C: Phenotype plasticity as enabler of melanoma progression and therapy resistance. Nat Rev Cancer 19: 377-391, 2019. PMID: 31209265. DOI: 10.1038/s41568-019$0154-4$

10 Gurzu S, Beleaua MA and Jung I: The role of tumor microenvironment in development and progression of malignant melanomas - a systematic review. Rom J Morphol Embryol 59: 23-28, 2018. PMID: 29940608.
11 Kasumova GG, Haynes AB and Boland GM: Lymphatic versus hematogenous melanoma metastases: Support for biological heterogeneity without clear clinical application. J Invest Dermatol 137: 2466-2468, 2017. PMID: 29169461. DOI: 10.1016/ j.jid.2017.08.029

12 Zbytek B, Carlson JA, Granese J, Ross J, Mihm MC Jr and Slominski A: Current concepts of metastasis in melanoma. Expert Rev Dermatol 3: 569-585, 2008. PMID: 19649148. DOI: 10.1586/17469872.3.5.569

13 Pearlman RL, Montes de Oca MK, Pal HC and Afaq F: Potential therapeutic targets of epithelial-mesenchymal transition in melanoma. Cancer Lett 391: 125-140, 2017. PMID: 28131904. DOI: 10.1016/j.canlet.2017.01.029

14 Shain AH and Bastian BC: From melanocytes to melanomas. Nat Rev Cancer 16: 345-358, 2016. PMID: 27125352. DOI: 10.1038/ nrc.2016.37

15 Valastyan S and Weinberg RA: Tumor metastasis: molecular insights and evolving paradigms. Cell 147: 275-292, 2011. PMID: 22000009. DOI: 10.1016/j.cell.2011.09.024

16 Disibio G and French SW: Metastatic patterns of cancers: results from a large autopsy study. Arch Pathol Lab Med 132: 931-939, 2008. PMID: 18517275. DOI: 10.1043/1542165(2008) 132[931:MPOCRF]2.0.CO;2

17 Patel JK, Didolkar MS, Pickren JW and Moore RH: Metastatic pattern of malignant melanoma. A study of 216 autopsy cases. Am J Surg 135: 807-810, 1978. PMID: 665907. DOI: 10.1016/00029610(78)90171-x

18 Everett L and Copperman T: Metastatic uveal melanoma. N Engl J 380: 1853, 2019. PMID: 31067375. DOI: 10.1056/ NEJMicm1810596

19 Bartel DP: Metazoan microRNAs. Cell 173: 20-51, 2018. PMID: 29570994. DOI: 10.1016/j.cell.2018.03.006

20 Lee Y, Kim M, Han J, Yeom KH, Lee S, Baek SH and Kim VN: MicroRNA genes are transcribed by RNA polymerase II. EMBO J 23: 4051-4060, 2004. PMID: 15372072. DOI: 10.1038/sj.emboj.7600385

$21 \mathrm{Du} \mathrm{T}$ and Zamore PD: microPrimer: the biogenesis and function of microRNA. Development 132: 4645-4652, 2005. PMID: 16224044. DOI: $10.1242 / \mathrm{dev} .02070$

22 Pillai RS: MicroRNA function: multiple mechanisms for a tiny RNA? RNA 11: 1753-1761, 2005. PMID: 16314451. DOI: 10.1261/rna.2248605

23 Bentwich I, Avniel A, Karov Y, Aharonov R, Gilad S, Barad O, Barzilai A, Einat P, Einav U, Meiri E, Sharon E, Spector Y and Bentwich Z: Identification of hundreds of conserved and nonconserved human microRNAs. Nat Genet 37: 766-770, 2005. PMID: 15965474. DOI: $10.1038 / n g 1590$

24 Valencia-Sanchez MA, Liu J, Hannon GJ and Parker R: Control of translation and mRNA degradation by miRNAs and siRNAs. Genes Dev 20: 515-524, 2006. PMID: 16510870. DOI: $10.1101 / \mathrm{gad} .1399806$

25 Lin S and Gregory RI: MicroRNA biogenesis pathways in cancer. Nat Rev Cancer 15: 321-333, 2015. PMID: 25998712. DOI: $10.1038 / \mathrm{nrc} 3932$

26 Peter ME: Targeting of mRNAs by multiple miRNAs: the next step. Oncogene 29: 2161-2164, 2010. PMID: 20190803. DOI: 10.1038/onc.2010.59

27 Calin GA and Croce CM: MicroRNA signatures in human cancers. Nat Rev Cancer 6: 857-866, 2006. PMID: 17060945. DOI: $10.1038 /$ nrc1997 
28 Di Leva G and Croce CM: Roles of small RNAs in tumor formation. Trends Mol Med 16: 257-267, 2010. PMID: 20493775. DOI: 10.1016/j.molmed.2010.04.001

29 Croce CM: Causes and consequences of microRNA dysregulation in cancer. Nat Rev Genet 10: 704-714, 2009. PMID: 19763153. DOI: $10.1038 / \mathrm{nrg} 2634$

30 Weidle UH, Dickopf S, Hintermair C, Kollmorgen G, Birzele F and Brinkmann U: The role of micro RNAs in breast cancer metastasis: preclinical validation and potential therapeutic targets. Cancer Genomics Proteomics 15: 17-39, 2018. PMID: 29275360. DOI: $10.21873 / \operatorname{cgp} .20062$

31 Weidle UH, Epp A, Birzele F and Brinkmann U: The functional role of prostate cancer metastasis-related micro-RNAs. Cancer Genomics Proteomics 16: 1-19, 2019. PMID: 30587496. DOI: 10.21873/cgp. 20108

32 Weidle UH, Birzele F and Nopora A: MicroRNAs as potential targets for therapeutic intervention with metastasis of non-small cell lung cancer. Cancer Genomics Proteomics 16: 99-119, 2019. PMID: 30850362. DOI: 10.21873/cgp.20116

33 Weidle UH, Birzele F, Kollmorgen G and Nopora A: Potential microRNA-related targets for therapeutic intervention with ovarian cancer metastasis. Cancer Genomics Proteomics 15:1-15, 2018. PMID: 29275359. DOI: $10.21873 / \operatorname{cgp} .20061$

34 Felicetti F, Errico C, L Bottero L, Segnalini P, Stoppacciaro A, Mauro Biffoni, Felli N, Mattia G and Petrini M, Colombo MP, Peschle $\mathrm{C}$ and Care A: The promyelocytic leukemia zinc fingerMicroRNA-221/-222 pathway controls melanoma progression through multiple oncogenic mechanisms. Cancer Res 15: 27452754, 2008. PMID: 18417445. DOI: 10.1158/0008-5472.CAN07-2538

35 Alexeev V and Yoon K: Distinctive role of the cKit receptor tyrosine kinase signaling in mammalian melanocytes. J Invest Dermatol 126: 1102-1110, 2006. PMID: 16410786. DOI: 10.1038/sj.jid.5700125

36 Hussein MR, Haemel AK and Wood GS: Apoptosis and melanoma: molecular mechanisms. J Pathol 199: 275-88, 2003. PMID: 12579529 . DOI: 10.1002/path. 1300

37 Li W, Sanki A, Karim RZ, Thompson JF, Soon Lee C, Zhuang L, McCarthy SW and Scolyer RA: The role of cell cycle regulatory proteins in the pathogenesis of melanoma. Pathology 38: 287-301, 2006. PMID: 16916716. DOI: 10.1080/00313020600817951

38 Sun M, Ma X, Tu C, Wang X, Qu J, Wang S and Xiao S: MicroRNA-378 regulates epithelial-mesenchymal transition and metastasis of melanoma by inhibiting FOXN3 expression through the Wnt/ß-catenin pathway. Cell Biol Int 43: 1113-1124, 2019. PMID: 29972255. DOI: 10.1002/cbin.11027

39 Kong X, Zhai J, Yan C, Song Y, Wang J, Bai X, Brown JAL and Fang Y: Recent advances in understanding FOXN3 in breast cancer, and other malignancies. Front Oncol 9: 234, 2019. PMID: 31214487. DOI: 10.3389/fonc.2019.00234

40 Long J, Menggen Q, Wuren Q, Shi Q and Pi X: MiR-219-5p inhibits the growth and metastasis of malignant melanoma by targeting BCL-2. Biomed Res Int 2017: 9032502, 2017. PMID: 28884131. DOI: $10.1155 / 2017 / 9032502$

41 Youle RJ and Strasser A: The BCL-2 protein family: opposing activities that mediate cell death. Nat Rev Mol Cell Biol 9: 4759, 2008. PMID: 18097445. DOI: 10.1038/nrm2308

42 Croce $\mathrm{CM}$ and Reed JC: Finally, an apoptosis-targeting therapeutic for cancer. Cancer Res 76: 5914-5920, 2016. PMID: 27694602. DOI: 10.1158/0008-5472.CAN-16-1248
43 Zhu Y, Zhang HL, Wang QY, Chen MJ and Liu LB: Overexpression of microRNA-612 restrains the growth, invasion, and tumorigenesis of melanoma cells by targeting espin. Mol Cells 41: 119-126, 2018. PMID: 29385671. DOI: 10.14348/ molcells. 2018

44 Taura A, Taura K, Koyama Y, Yamamoto N, Nakagawa T, Ito J and Ryan AF: Hair cell stereociliary bundle regeneration by espin gene transduction after aminoglycoside damage and hair cell induction by Notch inhibition. Gene Ther 23: 415-423, 2016. PMID: 26886463. DOI: 10.1038/gt.2016.12

45 Wang L, Zou J, Shen Z, Song E and Yang J: Whirlin interacts with espin and modulates its actin-regulatory function: an insight into the mechanism of Usher syndrome type II. Hum Mol Genet 1: 692-710, 2012. PMID: 22048959. DOI: $10.1093 / \mathrm{hmg} / \mathrm{ddr} 503$

46 Gaziel-Sovran A, Segura MF, Di Micco R, Collins MK, Hanniford D, Vega-Saenz de Miera E, Rakus JF, Dankert JF, Shang S, Kerbel RS, Bhardwaj N, Shao Y, Darvishian F, Zavadil J, Erlebacher A, Mahal LK, Osman I and Hernando E: miR$30 \mathrm{~b} / 30 \mathrm{~d}$ regulation of GalNAc transferases enhances invasion and immunosuppression during metastasis. Cancer Cell 20: 104-118, 2011. PMID: 21741600. DOI: 10.1016/j.ccr.2011.05.027

47 Ten Hagen KG, Fritz TA and Tabak LA: All in the family: the UDP-GalNAc: polypeptide N-acetylgalactosaminyltransferases. Glycobiology 13: 1R-16R, 2003. PMID: 12634319. DOI: 10.1093/glycob/cwg007

48 Segura MF, Hanniford D, Menendez S, Reavie L, Zou X, Alvarez-Diaz S, Zakrzewski J, Blochin E, Rose A, Bogunovic D Polsky D, Wei J, Lee P, Belitskaya-Levy I, Bhardwaj N, Osman I and Hernando E: Aberrant miR-182 expression promotes melanoma metastasis by repressing FOXO3 and microphthalmiaassociated transcription factor. Proc Natl Acad Sci USA 106 1814-1819, 2009. PMID: 19188590. DOI: $10.1073 /$ pnas. 0808263106

49 Myatt SS and Lam EW: The emerging roles of forkhead box (Fox) proteins in cancer. Nat Rev Cancer 7: 847-859, 2007. PMID: 17943136. DOI: $10.1038 / \mathrm{nrc} 2223$

50 Paik JH, Kollipara R, Chu G, Ji H, Xiao Y, Ding Z, Miao L, Tothova Z, Horner JW, Carrasco DR, Jiang S, Gilliland DG, Chin L, Wong WH, Castrillon DH and DePinho RA: FoxOs are lineage-restricted redundant tumor suppressors and regulate endothelial cell homeostasis. Cell 128: 309-323, 2007. PMID: 17254969. DOI: 10.1016/j.cell.2006.12.029

51 Reginato MJ, Mills KR, Paulus JK, Lynch DK, Sgroi DC, Debnath J, Muthuswamy SK and Brugge JS: Integrins and EGFR coordinately regulate the pro-apoptotic protein Bim to prevent anoikis. Nat Cell Biol 5: 733-740, 2003. PMID: 12844146. DOI: $10.1038 / \mathrm{ncb} 1026$

52 Garraway LA and Sellers WR: Lineage dependency and lineagesurvival oncogenes in human cancer. Nat Rev Cancer 6: 593-602, 2006. PMID: 16862190. DOI: $10.1038 / \mathrm{nrc} 1947$

53 Goding CR and Arnheiter H: MITF-the first 25 years. Genes and Devel 33: 983-1007, 2019. PMID: 31123060. DOI: 10.1101/gad.324657.119

54 Carreira S, Goodall J, Aksan I, La Rocca SA, Galibert MD, Denat L, Larue L and Goding CR: Mitf cooperates with Rb1 and activates p21Cip1 expression to regulate cell cycle progression. Nature 433: 764-769, 2005. PMID: 15716956. DOI: 10.1038/ nature 03269

55 Carreira S, Goodall J, Denat L, Rodriguez M, Nuciforo P, Hoek KS, Testori A, Larue L and Goding CR: Mitf regulation of Dia1 
controls melanoma proliferation and invasiveness. Genes Dev 20: 3426-3439, 2006. PMID: 17182868. DOI: 10.1101/gad.406406

56 Pencheva N, Tran H, Buss C, Huh D, Drobnjak M, Busam K and Tavazoie SF: Convergent multi-miRNA targeting of ApoE drives LRP1/LRP8-dependent melanoma metastasis and angiogenesis. Cell 151: 1068-1082, 2012. PMID: 23142051. DOI: 10.1016/j.cell.2012.10.028

57 Herz J and Strickland DK: LRP: a multifunctional scavenger and signaling receptor. J Clin Invest 108: 779-784, 2001. PMID: 11560943. DOI: $10.1172 / J C I 13992$

58 Xing P, Liao R, Zhao J, Song F, Wang G, Chen K and Yang J: Roles of low-density lipoprotein receptor-related protein 1 in tumors. Chin J Cancer 35: 6, 2016. PMID: 26738504. DOI: 10.1186/s40880-015-0064-0

59 Roslan Z, Muhamad M, Selvaratnam L and Ab-Rahim S: The roles of Low-density lipoprotein receptor-related proteins 5, 6, and 8 in cancer: A review. J Oncol 2019: 4536302, 2019. PMID: 31031810. DOI: $10.1155 / 2019 / 4536302$

60 Hatters DM, Peters-Libeu CA and Weisgraber $\mathrm{KH}$ : Apolipoprotein E structure: insights into function. Trends Biochem Sci 31: 445-454, 2006. PMID: 16820298. DOI: 10.1016/j.tibs.2006.06.008

61 Wu J, Liu T, Rios Z, Mei Q, Lin X and Cao S: Heat shock proteins and cancer. Trends Pharmacol Sci 38: 226-256, 2017. PMID: 28012700. DOI: 10.1016/j.tips.2016.11.009

62 Sun Z, Zhou S, Tang J, Ye T, Li J, Liu D, Zhou J, Wang J and Rosie Xing H: Sec23a mediates miR-200c augmented oligometastatic to polymetastatic progression. EBioMedicine 37: 47-55, 2018. PMID: 30301603. DOI: 10.1016/j.ebiom.2018.10.002

63 Fromme JC, Orci L and Schekman R: Coordination of COPII vesicle trafficking by Sec23. Trends Cell Biol 18: 330-336, 2008. PMID: 18534853. DOI: 10.1016/j.tcb.2008.04.006

64 Korpal M, Ell BJ, Buffa FM, Ibrahim T, Blanco MA, CeliàTerrassa T, Mercatali L, Khan Z, Goodarzi H, Hua Y, Wei Y, Hu G, Garcia BA, Ragoussis J, Amadori D, Harris AL and Kang Y: Direct targeting of Sec23a by miR-200s influences cancer cell secretome and promotes metastatic colonization. Nat Med 17: 1101-1108, 2011. PMID: 21822286. DOI: 10.1038/nm.2401

65 Huang T, Sun L, Yuan X and Qiu H: Thrombospondin-1 is a multifaceted player in tumor progression. Oncotarget 8: 845468455, 2017. PMID: 29137447. DOI: 10.18632/oncotarget.19165

66 Ryschich E, Huszty G, Knaebel HP, Hartel M, Büchler MW and Schmid R: Transferrin receptor is a marker of malignant phenotype in human pancreatic cancer and in neuroendocrine carcinoma of the pancreas. Eur J Cancer 40: 1418-1422, 2004. PMID: 15177502. DOI: 10.1016/j.ejca.2004.01.036

67 Poynter JN, Jacobs ET, Figueiredo JC, Lee WH, Conti DV, Campbell PT, Levine AJ, Limburg P, Le Marchand L, Cotterchio M, Newcomb PA, Potter JD, Jenkins MA, Hopper JL, Duggan DJ, Baron JA and Haile RW: Genetic variation in the vitamin D receptor (VDR) and the vitamin D-binding protein (GC) and risk for colorectal cancer: results from the colon cancer family registry. Cancer Epidemiol Biomarkers Prev 19: 525-536, 2010. PMID: 20086113. DOI: 10.1158/1055-9965.EPI-09-0662

68 Mishan MA, Ahmadiankia N and Bahrami AR: CXCR4 and CCR7: Two eligible targets in targeted cancer therapy. Cell Biol Int 240: 955-967, 2016. PMID: 27248053. DOI: 10.1002/ cbin. 10631

69 Xiong TF, Pan FQ and Li D: Expression and clinical significance of S100 family genes in patients with melanoma. Melanoma Res
29: 23-29, 2019. PMID: 30216200. DOI:10.1097/CMR.00000 00000000512

70 Penna E, Orso F, Cimino D, Tenaglia E, Lembo A, Quaglino E, Poliseno L, Haimovic A, Osella-Abate S, De Pittà C, Pinatel E, Stadler MB, Provero P, Bernengo MG, Osman I and Taverna D: microRNA-214 contributes to melanoma tumour progression through suppression of TFAP2C. EMBO J 30: 1990-2007, 2011. PMID: 21468029. DOI: 10.1038/emboj.2011.102

71 Penna E, Orso F, Cimino D, Vercellino I, Grassi E, Quaglino E, Turco E and Taverna D: miR-214 coordinates melanoma progression by upregulating ALCAM through TFAP2 and miR148b downmodulation. Cancer Res 73: 4098-4111, 2013. PMID: 23667173. DOI: 10.1158/0008-5472.CAN-12-3686

72 Orso F, Quirico L, Virga F, Penna E, Dettori D, Cimino D, Coppo R, Grassi E, Elia AR, Brusa D, Deaglio S, Brizzi MF, Stadler MB, Provero P, Caselle M and Taverna D: miR-214 and miR-148b targeting inhibits dissemination of melanoma and breast cancer. Cancer Res 76: 5151-5162, 2016. PMID: 27328731. DOI: 10.1158/0008-5472.CAN-15-1322

73 Huang R and Rofstad EK: Integrins as therapeutic targets in the organ-specific metastasis of human malignant melanoma. J Exp Clin Cancer Res 37: 92, 2018. PMID: 29703238. DOI: 10.1186/s13046-018-0763-x

74 Bar-Eli M: Searching for the 'melano-miRs': miR-214 drives melanoma metastasis. EMBO J 30: 1880-1881, 2011. PMID: 21593728. DOI: $10.1038 /$ emboj.2011.132

75 Kołat D, Kałuzińska Ż, Bednarek AK and Płuciennik E: The biological characteristics of transcription factors AP- $2 \alpha$ and AP$2 \gamma$ and their importance in various types of cancers. Biosci Rep 39: pii: BSR20181928, 2019. PMID: 30824562. DOI: 10.1042/BSR20181928

76 van Kempen LC, van den Oord JJ, van Muijen GN, Weidle UH, Bloemers HP and Swart GW: Activated leukocyte cell adhesion molecule/CD166, a marker of tumor progression in primary malignant melanoma of the skin. Am J Pathol 156: 769-774, 2000. PMID: 10702391. DOI: 10.1016/S0002-9440(10)64943-7

77 Weidle UH, Eggle D, Klostermann S and Swart GW: ALCAM/CD166: cancer-related issues. Cancer Genomics Proteomics 7: 231-243, 2010. PMID: 20952758.

78 Dettori D, Orso F, Penna E, Baruffaldi D, Brundu S, Maione F, Turco E, Giraudo E and Taverna D: Therapeutic silencing of miR214 inhibits tumor progression in multiple mouse models. Mol Ther 26: 2008-2018, 2018. PMID: 29929788. DOI: 10.1016/j.ymthe.2018.05.020

79 Bhattacharya A, Schmitz U, Raatz Y, Schönherr M, Kottek T, Schauer M, Franz S, Saalbach A, Anderegg U, Wolkenhauer O, Schadendorf D, Simon JC, Magin T, Vera J and Kunz M: miR638 promotes melanoma metastasis and protects melanoma cells from apoptosis and autophagy. Oncotarget 6: 2966-2980, 2015. PMID: 25650662. DOI: 10.18632/oncotarget.3070

80 Shahbazi J, Lock R and Liu T: Tumor protein 53-induced nuclear protein 1 enhances p53 function and represses tumorigenesis. Front Genet 4: 80, 2013. PMID: 23717325. DOI: 10.3389/fgene. 2013.00080

81 Seillier M, Peuget S, Gayet O, Gauthier C, N'Guessan P, Monte M, Carrier A, Iovanna JL and Dusetti NJ: TP53INP1, a tumor suppressor, interacts with LC3 and ATG8-family proteins through the LC3-interacting region (LIR) and promotes autophagydependent cell death. Cell Death Differ 19: 1525-1535, 2012. PMID: 22421968. DOI: 10.1038/cdd.2012.30 
82 Guo W, Wang H, Yang Y, Guo S, Zhang W, Liu Y, Yi X, Ma J, Zhao T, Liu L, Jian Z, Liu L, Wang G, Gao T, Shi Q and Li C: Down-regulated miR-23a contributes to the metastasis of cutaneous melanoma by promoting autophagy. Theranostics 7: 2231-2249, 2017. PMID: 28740547. DOI: 10.7150/thno.18835

83 Deiana M, Dalle Carbonare L, Serena M, Cheri S, Parolini F, Gandini A, Marchetto G, Innamorati G, Manfredi M, Marengo E, Brandi J, Cecconi D, Mori A, Mina MM, Antoniazzi F, Mottes M, Tiso N, Malerba G, Zipeto D and Valenti MT: New insights into the runt domain of RUNX2 in melanoma cell proliferation and migration. Cells 7: pii: E220, 2018. PMID: 30463392. DOI: 10.3390/cells 7110220

84 Rubinstein AD, Eisenstein M, Ber Y, Bialik S and Kimchi A: The autophagy protein Atg12 associates with antiapoptotic Bcl-2 family members to promote mitochondrial apoptosis. Mol Cell 44: 698-709, 2011. PMID: 22152474. DOI: 10.1016/j.molcel. 2011.10.014

85 Noda NN and Inagaki F: Mechanisms of autophagy. Annu Rev Biophys 44: 101-22, 2015. PMID: 25747593. DOI: 10.1146/annurev-biophys-060414-034248

86 Cerezo M, Tichet M, Abbe P, Ohanna M, Lehraiki A, Rouaud F, Allegra M, Giacchero D, Bahadoran P, Bertolotto C, TartareDeckert S, Ballotti R and Rocchi S: Metformin blocks melanoma invasion and metastasis development in AMPK/p53-dependent manner. Mol Cancer Ther 12: 1605-1615, 2013. PMID: 23741061. DOI: 10.1158/1535-7163.MCT-12-1226-T

87 Gayard M, Guilluy C, Rousselle A, Viollet B, Henrion D, Pacaud P, Loirand G and Rolli-Derkinderen M: AMPK alpha 1-induced RhoA phosphorylation mediates vasoprotective effect of estradiol. Arterioscler Thromb Vasc Biol 31: 2634-2642, 2011. PMID: 21852563. DOI: 10.1161/ATVBAHA.111.228304

88 Sadok A, McCarthy A, Caldwell J, Collins I, Garrett MD, Yeo M, Hooper S, Sahai E, Kuemper S, Mardakheh FK and Marshall CJ: Rho kinase inhibitors block melanoma cell migration and inhibit metastasis. Cancer Res 75: 2272-2284, 2015. PMID: 25840982. DOI: 10.1158/0008-5472.CAN-14-2156

89 Noori J, Sharifi M and Haghjooy Javanmard S: miR-30a inhibits melanoma tumor metastasis by targeting the E-cadherin and zinc finger E-box binding homeobox 2. Adv Biomed Res 7:143, 2018. PMID: 30596053. DOI: 10.4103/abr.abr_146_18

90 Comijn J, Berx G, Vermassen P, Verschueren K, van Grunsven L, Bruyneel E, Mareel M, Huylebroeck D and van Roy F: The twohanded $\mathrm{E}$ box binding zinc finger protein SIP1 downregulates Ecadherin and induces invasion. Mol Cell 7: 1267-1277, 2001. PMID: 11430829.

91 Zhang J, Zhang H, Liu J, Tu X, Zang Y, Zhu J, Chen J, Dong L and Zhang J: miR-30 inhibits TGF- $\beta 1$-induced epithelial-tomesenchymal transition in hepatocyte by targeting Snail1. Biochem Biophys Res Commun 417: 1100-1105, 2012. PMID: 22227196. DOI: 10.1016/j.bbrc.2011.12.121

92 Kumarswamy R, Mudduluru G, Ceppi P, Muppala S, Kozlowski M, Niklinski J, Papotti M and Allgayer H: MicroRNA-30a inhibits epithelial-to-mesenchymal transition by targeting Snai1 and is downregulated in non-small cell lung cancer. Int J Cancer 130: 2044-2453, 2012. PMID: 21633953. DOI: 10.1002/ ijc. 26218

93 Zhang J, Na S, Liu C, Pan S, Cai J and Qiu J: MicroRNA-125b suppresses the epithelial-mesenchymal transition and cell invasion by targeting ITGA9 in melanoma. Tumour Biol 37: 5941-5949, 2016. PMID: 26596831. DOI: 10.1007/s13277-015-4409-8
94 Gupta SK, Oommen S, Aubry MC, Williams BP, Vlahakis NE, Zhang J, Na S, Liu C, Pan S, Cai J and Qiu J: Integrin $\alpha 9 \beta 1$ promotes malignant tumor growth and metastasis by potentiating epithelial-mesenchymal transition. Oncogene 32: 141-150, 2013. PMID: 22370635. DOI: 10.1038/onc.2012.41

95 Rang Z, Yang G, Wang YW and Cui F: miR-542-3p suppresses invasion and metastasis by targeting the proto-oncogene serine/threonine protein kinase, PIM1, in melanoma. Biochem Biophys Res Commun 474: 315-320, 2016. PMID: 27107696. DOI: 10.1016/j.bbrc.2016.04.093

96 Santio NM and Koskinen PJ: PIM kinases: From survival factors to regulators of cell motility. Int J Biochem Cell Biol 93: 74-85, 2017. PMID: 29108877. DOI: 10.1016/j.biocel.2017.10.016

97 Tursynbay Y, Zhang J, Li Z, Tokay T, Zhumadilov Z, Wu D and Xie Y: Pim-1 kinase as cancer drug target: An update. Biomed Rep 4: 140-146, 2016. PMID: 26893828. DOI: 10.3892/br.2015.561

98 Giles KM, Brown RA, Ganda C, Podgorny MJ, Candy PA, Wintle LC, Richardson KL, Kalinowski FC, Stuart LM, Epis MR, Haass NK, Herlyn $M$ and Leedman PJ: microRNA-7-5p inhibits melanoma cell proliferation and metastasis by suppressing RelA/NF-kB. Oncotarget 7: 31663-31680, 2016. PMID: 27203220. DOI: 10.18632/oncotarget.9421

99 Kaltschmidt B, Greiner JFW, Kadhim HM and Kaltschmidt C: Subunit-Specific Role of NF-kB in Cancer. Biomedicines 6(2): 44, 2018. PMID: 29673141. DOI: 10.3390/biomedicines6020044

100 Xia L, Tan S, Zhou Y, Lin J, Wang H, Oyang L, Tian Y, Liu L, Su M, Wang H, Cao D and Liao Q: Role of the NFkB-signaling pathway in cancer. Onco Targets Ther 11: 2063-2073, 2018. PMID: 29695914. DOI: 10.2147/OTT.S161109

101 Li F, Li XJ, Qiao L, Shi F, Liu W, Li Y, Dang YP, Gu WJ, Wang XG and Liu W: miR-98 suppresses melanoma metastasis through a negative feedback loop with its target gene IL-6. Exp Mol Med 46: e116, 2014. PMID: 25277211. DOI: 10.1038/emm.2014.63

102 Naugler WE and Karin M: The wolf in sheep's clothing: the role of interleukin-6 in immunity, inflammation and cancer. Trends Mol Med 14: 109-119, 2008. PMID: 18261959. DOI: 10.1016/j.molmed.2007.12.007

103 Weidle UH, Klostermann S, Eggle D and Krüger A: Interleukin 6/interleukin 6 receptor interaction and its role as a therapeutic target for treatment of cachexia and cancer. Cancer Genomics Proteomics 7: 287-302, 2010. PMID: 21156962.

104 Hoejberg L, Bastholt L and Schmidt H: Interleukin-6 and melanoma. Melanoma Res 22: 327-333, 2012. PMID: 22713796. DOI: $10.1097 / C M R .0 b 013 e 3283543 \mathrm{~d} 72$

105 Weber CE, Luo C, Hotz-Wagenblatt A, Gardyan A, Kordaß T, Holland-Letz T, Osen W and Eichmüller SB: miR-339-3p is a tumor suppressor in melanoma. Cancer Res 76: 3562-3571, 2016. PMID: 27197185. DOI: 10.1158/0008-5472.CAN-15-2932

106 Boisvert-Adamo K, Longmate W, Abel EV and Aplin AE: Mcl-1 is required for melanoma cell resistance to anoikis. Mol Cancer Res 7: 549-556, 2009. PMID: 19372583. DOI: 10.1158/15417786.MCR-08-0358

107 Fofaria NM, Frederick DT, Sullivan RJ, Flaherty KT and Srivastava SK: Overexpression of Mcl-1 confers resistance to BRAFV600E inhibitors alone and in combination with MEK1/2 inhibitors in melanoma. Oncotarget 6: 40535-40556, 2015. PMID: 26497853. DOI: 10.18632/oncotarget.5755

108 Hird AW and Tron AE: Recent advances in the development of Mcl-1 inhibitors for cancer therapy. Pharmacol Ther 198: 59-67, 2019. PMID: 30790641. DOI: 10.1016/j.pharmthera.2019.02.007 
109 Senichkin VV, Streletskaia AY, Zhivotovsky B and Kopeina GS: Molecular comprehension of Mcl-1: From gene structure to cancer therapy. Trends Cell Biol 29: 549-562, 2019. PMID: 31030977. DOI: 10.1016/j.tcb.2019.03.004

110 Yang $\mathrm{CH}$, Yue J, Pfeffer SR, Handorf CR and Pfeffer LM: MicroRNA miR-21 regulates the metastatic behavior of B16 melanoma cells. J Biol Chem 286: 39172-39178, 2011. PMID: 21940630. DOI: 10.1074/jbc.M111.285098

111 Lee YR, Chen M and Pandolfi PP: The functions and regulation of the PTEN tumour suppressor: new modes and prospects. Nat Rev Mol Cell Biol 19: 547-562, 2018. PMID: 29858604. DOI: 10.1038/s41580-018-0015-0

112 Matsuhashi S, Manirujjaman M, Hamajima H and Ozaki I: Control mechanisms of the tumor suppressor PDCD4: Expression and functions. Int J Mol Sci 20: pii: E2304, 2019. PMID: 31075975. DOI: $10.3390 /$ ijms20092304

113 Mao B, Zhang Z and Wang G: BTG2: a rising star of tumor suppressors (review). Int J Oncol 46: 459-464, 2015. PMID: 25405282. DOI: $10.3892 /$ ijo.2014.2765

114 Yuniati L, Scheijen B, van der Meer LT and van Leeuwen FN: Tumor suppressors BTG1 and BTG2: Beyond growth control. J Cell Physiol 234: 5379-5389, 2019. PMID: 30350856. DOI: $10.1002 /$ jcp. 27407

115 Saldanha G, Potter L, Lee YS, Watson S, Shendge P and Pringle JH: MicroRNA-21 expression and its pathogenetic significance in cutaneous melanoma. Melanoma Res 26: 21-28, 2016. PMID: 26731559. DOI: 10.1097/CMR.0000000000000216

116 Raimo M, Orso F, Grassi E, Cimino D, Penna E, De Pittà C, Stadler MB, Primo L, Calautti E1, Quaglino P, Provero P and Taverna D: miR-146a exerts differential effects on melanoma growth and metastatization. Mol Cancer Res 14: 548-562, 2016. PMID: 27311960. DOI: 10.1158/1541-7786.MCR-150425-T

117 Forloni M, Dogra SK, Dong Y, Conte D Jr, Ou J, Zhu LJ, Deng A, Mahalingam M, Green MR and Wajapeyee N: miR-146a promotes the initiation and progression of melanoma by activating Notch signaling. Elife 18: e01460, 2014. PMID: 24550252. DOI: 10.7554/eLife. 01460

118 Xu K, Usary J, Kousis PC, Prat A, Wang DY, Adams JR, Wang W, Loch AJ, Deng T, Zhao W, Cardiff RD, Yoon K, Gaiano N, Ling V, Beyene J, Zacksenhaus E, Gridley T, Leong WL, Guidos CJ, Perou CM, and Egan SE: Lunatic fringe deficiency cooperates with the Met/Caveolin gene amplicon to induce basal-like breast cancer. Cancer Cell 21: 626-641, 2012. PMID: 226247. DOI: 10.1016/j.ccr.2012.03.041

119 Moloney DJ, Panin VM, Johnston SH, Chen J, Shao L, Wilson R, Wang Y, Stanley P, Irvine KD, Haltiwanger RS and Vogt TF: Fringe is a glycosyltransferase that modifies Notch. Nature 406: 369-375, 2000. PMID: 10935626. DOI: 10.1038/ 35019000

120 Spana EP and Doe CQ: Numb antagonizes Notch signaling to specify sibling neuron cell fates. Neuron 17: 21-26, 1996. PMID: 8755475.

121 Sanz-Moreno V: Tumour invasion: a new twist on Rac-driven mesenchymal migration. Curr Biol 22: R449-R451, 2012. PMID: 22677287. DOI: 10.1016/j.cub.2012.04.024

122 Julian L and Olson MF: Rho-associated coiled-coil containing kinases (ROCK): structure, regulation, and functions. Small GTPases 5: e29846, 2014. PMID: 25010901. DOI: 10.4161/sgtp. 29846
123 Aspenström P: Activated Rho GTPases in cancer-the beginning of a new paradigm. Int J Mol Sci 19: pii: E3949, 2018. PMID: 30544828. DOI: 10.3390/ijms19123949

124 Shoshan E, Mobley AK, Braeuer RR, Kamiya T, Huang L, Vasquez ME, Salameh A, Lee HJ, Kim SJ, Ivan C, VelazquezTorres G, Nip KM, Zhu K, Brooks D, Jones SJ, Birol I, Mosqueda M, Wen YY, Eterovic AK, Sood AK, Hwu P, Gershenwald JE, Robertson AG, Calin GA, Markel G, Fidler IJ and Bar-Eli M: Reduced adenosine-to-inosine miR-455-5p editing promotes melanoma growth and metastasis. Nat Cell Biol 17: 311-321, 2015. PMID: 25686251. DOI: $10.1038 / \mathrm{ncb} 3110$

125 Maas S, Rich A and Nishikura K: A-to-I RNA editing: Recent news and residual mysteries. J Biol Chem 278: 1391-1394, 2003. PMID: 12446659. DOI: 10.1074/jbc.R200025200

126 Kawahara Y, Zinshteyn B, Chendrimada TP, Shiekhattar R and Nishikura K: RNA editing of the microRNA-151 precursor blocks cleavage by the Dicer-TRBP complex. EMBO Rep 8: 763-769, 2007. PMID: 17599088. DOI: 10.1038/sj.embor.7401011

127 Mendez R and Richter JD: Translational control by CPEB: a means to the end. Nat Rev Mol Cell Biol 2: 521-529, 2001. PMID: 11433366. DOI: 10.1038/35080081

128 Chen Y, Tsai YH and Tseng SH: Regulation of the expression of cytoplasmic polyadenylation element binding proteins for the treatment of cancer. Anticancer Res 36: 5673-5680, 2016. PMID: 27793888. DOI: 10.21873/anticanres. 11150

129 Caldeira J, Simões-Correia J, Paredes J, Pinto MT, Sousa S, Corso G, Marrelli D, Roviello F, Pereira PS, Weil D, Oliveira C, Casares F and Seruca R: CPEB1, a novel gene silenced in gastric cancer: a drosophila approach. Gut 61: 1115-1123, 2012. PMID: 22052064. DOI: 10.1136/gutjnl-2011-300427

130 Zhang JH, Panicker LM, Seigneur EM, Lin L, House CD, Morgan W, Chen WC, Mehta H, Haj-Ali M, Yu ZX and Simonds WF: Cytoplasmic polyadenylation element binding protein is a conserved target of tumor suppressor HRPT2/CDC73. Cell Death Differ 17: 1551-1565, 2010. PMID: 20339377. DOI: $10.1038 /$ cdd 2010.32

131 Zhou J, Xu D, Xie H, Tang J, Liu R, Li J, Wang S, Chen X, Su J, Zhou X, Xia K, He Q, Chen J, Xiong W, Cao P and Cao K: miR33a functions as a tumor suppressor in melanoma by targeting HIF-1 $\alpha$. Cancer Biol Ther 16: 846-855, 2015. PMID: 25891797. DOI: $10.1080 / 15384047.2015 .1030545$

132 Nys K, Maes H, Dudek AM and Agostinis P: Uncovering the role of hypoxia inducible factor- $1 \alpha$ in skin carcinogenesis. Biochim Biophys Acta 1816: 1-12, 2011. PMID: 21338656. DOI: 10.1016/j.bbcan.2011.02.001

133 Hanna SC, Krishnan B, Bailey ST, Moschos SJ, Kuan PF, Shimamura T, Osborne LD, Siegel MB, Duncan LM, O'Brien ET 3rd, Superfine R, Miller CR, Simon MC, Wong KK and Kim WY: HIF $1 \alpha$ and HIF $2 \alpha$ independently activate SRC to promote melanoma metastases. J Clin Invest 123: 2078-2093, 2013. PMID: 23563312. DOI: $10.1172 / \mathrm{JCI} 66715$

134 Cheli Y, Giuliano S, Fenouille N, Allegra M, Hofman V, Hofman P, Bahadoran P, Lacour JP, Tartare-Deckert S, Bertolotto C and Ballotti R: Hypoxia and MITF control metastatic behaviour in mouse and human melanoma cells. Oncogene 31: 2461-2470, 2012. PMID: 21996743. DOI: 10.1038/onc.2011.425

135 Giatromanolaki A, Sivridis E, Kouskoukis C, Gatter KC, Harris $\mathrm{AL}$ and Koukourakis MI: Hypoxia-inducible factors 1alpha and 2alpha are related to vascular endothelial growth factor expression and a poorer prognosis in nodular malignant melanomas of the 
skin. Melanoma Res 13: 493-501, 2003. PMID: 14512791. DOI: 10.1097/01.cmr.0000056268.56735.4c

136 Liu S, Tetzlaff MT, Cui R and Xu X: miR-200c inhibits melanoma progression and drug resistance through downregulation of BMI-1. Am J Pathol 181: 1823-1835, 2012. PMID: 22982443. DOI: 10.1016/j.ajpath.2012.07.009

137 Sherr CJ: The INK4a/ARF network in tumour suppression. Nat Rev Mol Cell Biol 2: 731-737, 2001. PMID: 11584300. DOI: $10.1038 / 35096061$

138 Jacobs JJ, Kieboom K, Marino S, DePinho RA and van Lohuizen $\mathrm{M}$ : The oncogene and polycomb-group gene bmi-1 regulates cell proliferation and senescence through the ink4a locus. Nature 397: 164-168, 1999. PMID: 9923679. DOI: 10.1038/16476

139 Schatton T, Murphy GF, Frank NY, Yamaura K, Waaga-Gasser AM, Gasser M, Zhan Q, Jordan S, Duncan LM, Weishaupt C, Fuhlbrigge RC, Kupper TS, Sayegh $\mathrm{MH}$ and Frank MH: Identification of cells initiating human melanomas. Nature 451: 345-349, 2008. PMID: 18202660. DOI: 10.1038/nature06489

140 Chen KG, Szakács G, Annereau JP, Rouzaud F, Liang XJ, Valencia JC, Nagineni CN, Hooks JJ, Hearing VJ and Gottesman MM: Principal expression of two mRNA isoforms (ABCB 5alpha and ABCB 5beta) of the ATP-binding cassette transporter gene ABCB 5 in melanoma cells and melanocytes. Pigment Cell Res 18: 102-112, 2005. PMID: 15760339. DOI: 10.1111/j.16000749.2005.00214.x

141 Mihic-Probst D, Kuster A, Kilgus S, Bode-Lesniewska B, IngoldHeppner B, Leung C, Storz M, Seifert B, Marino S, Schraml P, Dummer R and Moch H: Consistent expression of the stem cell renewal factor BMI-1 in primary and metastatic melanoma. Int J Cancer 121: 1764-1770, 2007. PMID: 17597110. DOI: 10.1002/ijc. 22891

142 Wellner U, Schubert J, Burk UC, Schmalhofer O, Zhu F, Sonntag A, Waldvogel B, Vannier C, Darling D, zur Hausen A, Brunton VG, Morton J, Sansom O, Schüler J, Stemmler MP, Herzberger C, Hopt U, Keck T, Brabletz S and Brabletz T: The EMT-activator ZEB1 promotes tumorigenicity by repressing stemness-inhibiting microRNAs. Nat Cell Biol 11: 1487-1495, 2009. PMID: 19935649. DOI: $10.1038 /$ ncb1998

$143 \mathrm{Xu}$ Y, Brenn T, Brown ER, Doherty V and Melton DW: Differential expression of microRNAs during melanoma progression: miR-200c, miR-205 and miR-211 are downregulated in melanoma and act as tumour suppressors. $\mathrm{Br} \mathrm{J}$ Cancer 106: 553-561, 2012. PMID: 22223089. DOI: 10.1038/bjc.2011.568

144 Lohcharoenkal W, Das Mahapatra K, Pasquali L, Crudden C, Kular L, Akkaya Ulum YZ, Zhang L, Xu Landén N, Girnita L, Jagodic M, Ståhle M, Sonkoly E and Pivarcsi A: Genome-wide screen for microRNAs reveals a role for miR-203 in melanoma metastasis. J Invest Dermatol 138: 882-892, 2018. PMID: 29104160. DOI: 10.1016/j.jid.2017.09.049

145 Cho ES, Kang HE, Kim NH and Yook JI: Therapeutic implications of cancer epithelial-mesenchymal transition (EMT). Arch Pharm Res 42: 14-24, 2009. PMID: 30649699. DOI: 10.1007/s 12272-018-01108-7

146 Gupta PB, Kuperwasser C, Brunet JP, Ramaswamy S, Kuo WL, Gray JW, Naber SP and Weinberg RA: The melanocyte differentiation program predisposes to metastasis after neoplastic transformation. Nat Genet 37: 1047-1054, 2005. PMID: 16142232. DOI: $10.1038 / n g 1634$

147 Shih JY, Tsai MF, Chang TH, Chang YL, Yuan A, Yu CJ, Lin SB, Liou GY, Lee ML, Chen JJ, Hong TM, Yang SC, Su JL, Lee YC and Yang PC: Transcription repressor slug promotes carcinoma invasion and predicts outcome of patients with lung adenocarcinoma. Clin Cancer Res 11: 8070-8078, 2005. PMID: 16299238. DOI: 10.1158/1078-0432.CCR-05-0687

148 Shioiri M, Shida T, Koda K, Oda K, Seike K, Nishimura M, Takano S and Miyazaki M: Slug expression is an independent prognostic parameter for poor survival in colorectal carcinoma patients. Br J Cancer 94: 1816-1822, 2006. PMID: 16773075. DOI: $10.1038 /$ sj.bjc.6603193

149 Bai J, Zhang Z, Li X and Liu H: MicroRNA-365 inhibits growth, invasion and metastasis of malignant melanoma by targeting NRP1 expression. Int J Clin Exp Pathol 8: 4913-4922, 2015. PMID: 26191184.

150 Graziani G and Lacal PM: Neuropilin-1 as therapeutic target for malignant melanoma. Front Oncol 5: 125, 2015. PMID: 26090340. DOI: 10.3389/fonc.2015.00125

151 Bagri A, Tessier-Lavigne M and Watts RJ: Neuropilins in tumor biology. Clin Cancer Res 15: 1860-1864, 2009. PMID: 19240167. DOI: $10.1158 / 1078-0432 . C C R-08-0563$

152 Niland S and Eble JA: Neuropilins in the context of tumor vasculature. Int J Mol Sci 20: pii: E639, 2019. PMID: 30717262. DOI: $10.3390 /$ ijms 20030639

153 Hanniford D, Segura MF, Zhong J, Philips E, Jirau-Serrano X, Darvishian F, Berman RS, Shapiro RL, Pavlick AC, Brown B, Osman I and Hernando E: Identification of metastasis-suppressive microRNAs in primary melanoma. J Natl Cancer Inst 107: pii: dju494, 2015. PMID: 25677173. DOI: 10.1093/jnci/dju494

154 Cosen-Binker LI and Kapus A: Cortactin: The gray eminence of the cytoskeleton. Physiology (Bethesda) 21: 352-361, 2006. PMID: 16990456. DOI: 10.1152/physiol.00012.2006

155 Murphy DA and Courtneidge SA: The 'ins' and 'outs' of podosomes and invadopodia: characteristics, formation and function. Nat Rev Mol Cell Biol 12: 413-426, 2011. PMID: 21697900. DOI: $10.1038 / \mathrm{nrm} 3141$

156 Goley ED1 and Welch MD: The ARP2/3 complex: an actin nucleator comes of age. Nat Rev Mol Cell Biol 7: 713-726, 2006. PMID: 16990851. DOI: 10.1038/nrm2026

157 Smith LG and Li R: Actin polymerization: riding the wave. Curr Biol 14: R109-R111, 2004. PMID: 14986640.

158 Eden S, Rohatgi R, Podtelejnikov AV, Mann M and Kirschner MW: Mechanism of regulation of WAVE1-induced actin nucleation by Rac1 and Nck. Nature 418: 790-793, 2002. PMID: 12181570. DOI: $10.1038 /$ nature00859

159 Pekarsky Y, Balatti V and Croce CM: BCL2 and miR-15/16: from gene discovery to treatment. Cell Death Differ 25: 21-26, 2018. PMID: 28984869. DOI: 10.1038/cdd.2017.159

160 Weekes CD, Beeram M, Tolcher AW, Papadopoulos KP, Gore L, Hegde P, Xin Y, Yu R, Shih LM, Xiang H, Brachmann RK and Patnaik A: A phase I study of the human monoclonal anti-NRP1 antibody MNRP1685A in patients with advanced solid tumors Invest New Drugs 32: 653-660, 2014. PMID: 24604265. DOI: 10.1007/s10637-014-0071-z

161 Johnson DE, O'Keefe RA and Grandis JR: Targeting the IL6/JAK/STAT3 signalling axis in cancer. Nat Rev Clin Oncol 15: 234-248, 2018. PMID: 29405201. DOI: 10.1038/nrclinonc. 2018.8

162 Steeg PS: Targeting metastasis. Nat Rev Cancer 16: 201-218, 2016. PMID: 27009393. DOI: $10.1038 /$ nrc. 2016.25

163 Auslander N, Zhang G, Lee JS, Frederick DT, Miao B, Moll T, Tian T, Wei Z, Madan S, Sullivan RJ, Boland G, Flaherty K, Herlyn $\mathrm{M}$ and Ruppin E: Robust prediction of response to 
immune checkpoint blockade therapy in metastatic melanoma. Nat Med 24: 1545-1549, 2018. PMID: 30127394. DOI: 10.1038/s41591-018-0157-9

164 Karivedu V, Eldessouki I, Taftaf A, Zhu Z, Makramalla A and Karim NA: Nivolumab and Ipilimumab in the treatment of metastatic uveal melanoma: A single-center experience. Case Rep Oncol Med 2019: 3560640, 2019. PMID: 31179139. DOI: $10.1155 / 2019 / 3560640$

165 Kilickap S, Guven DC, Aktepe OH, Aktas BY and Dizdar O: Complete responses to two different anti-PD1 agents in a metastatic melanoma patient. J Oncol Pharm Pract 29: 1078155219858657, 2019. PMID: 31256744. DOI: $10.1177 / 1078155219858657$

166 Anderson RL, Balasas T, Callaghan J, Coombes RC, Evans J, Hall JA, Kinrade S, Jones D, Jones PS, Jones R, Marshall JF, Panico MB, Shaw JA, Steeg PS, Sullivan M, Tong W, Westwell AD, Ritchie JWA; Cancer Research UK and Cancer Therapeutics CRC Australia Metastasis Working Group. A framework for the development of effective anti-metastatic agents. Nat Rev Clin Oncol 16: 185-204, 2019. PMID: 30514977. DOI: 10.1038/s41571-018-0134-8

167 Ling H, Fabbri M and Calin GA: MicroRNAs and other noncoding RNAs as targets for anticancer drug development. Nat Rev Drug Discov 12: 847-865, 2013. PMID: 24172333. DOI: $10.1038 /$ nrd4140

168 Gambari R, Brognara E, Spandidos DA and Fabbri E: Targeting oncomiRNAs and mimicking tumor suppressor miRNAs: New trends in the development of miRNA therapeutic strategies in oncology (Review). Int J Oncol 49: 5-32, 2016. PMID: 27175518. DOI: 10.3892/ijo.2016.3503

169 Broderick JA and Zamore PD: MicroRNA therapeutics. Gene Ther 18: 1104-1110, 2011. PMID: 21525952. DOI: 10.1038/gt.2011.50

170 MacLeod AR and Crooke ST: RNA therapeutics in oncology: Advances, challenges, and future directions. J Clin Pharmacol 57(Suppl 10): S43-S59, 2017. PMID: 21525952. DOI: $10.1038 /$ gt.2011.50

$171 \mathrm{Li} \mathrm{Z}$ and Rana TM: Therapeutic targeting of microRNAs: Current status and future challenges. Nat Rev Drug Discov 13: 622-638, 2014. PMID: 25011539 . DOI: $10.1038 / \operatorname{nrd} 4359$

172 Garofalo M, Leva GD and Croce CM: MicroRNAs as anti-cancer therapy. Curr Pharm Des 20: 5328-5335, 2014. PMID: 24479801. DOI: $10.2174 / 1381612820666140128211346$

173 Malek A, Merkel O, Fink L, Czubayko F, Kissel T and Aigner A: In vivo pharmacokinetics, tissue distribution and underlying mechanisms of various PEI(-PEG)/siRNA complexes. Toxicol Appl Pharmacol 236: 97-108, 2009. PMID: 19371615. DOI: 10.1016/j.taap.2009.01.014
174 Wang AZ, Langer R and Farokhzad OC: Nanoparticle delivery of cancer drugs. Annu Rev Med 63: 185-198, 2012. PMID: 21888516. DOI: 10.1146/annurev-med-040210-162544

175 Rozema DB, Lewis DL, Wakefield DH, Wong SC, Klein JJ, Roesch PL, Bertin SL, Reppen TW, Chu Q, Blokhin AV, Hagstrom JE and Wolff JA: Dynamic PolyConjugates for targeted in vivo delivery of siRNA to hepatocytes. Proc Natl Acad Sci USA 104: 12982-12987, 2007. PMID: 17652171. DOI: 10.1073/pnas.0703778104

176 Kanasty R, Dorkin JR, Vegas A and Anderson D: Delivery materials for siRNA therapeutics. Nat Mater 12: 967-977, 2013. PMID: 24150415. DOI: 10.1038/nmat3765

177 Nair JK, Willoughby JL, Chan A, Charisse K, Alam MR, Wang Q, Hoekstra M, Kandasamy P, Kel'in AV, Milstein S, Taneja N, O'Shea J, Shaikh S, Zhang L, van der Sluis RJ, Jung ME, Akinc A, Hutabarat R, Kuchimanchi S, Fitzgerald K, Zimmermann T, van Berkel TJ, Maier MA, Rajeev KG and Manoharan M: Multivalent $\mathrm{N}$-acetylgalactosamine-conjugated siRNA localizes in hepatocytes and elicits robust RNAi-mediated gene silencing. J Am Chem Soc 136: 16958-16961, 2014. PMID: 25434769. DOI: 10.1021/ja505986a

178 Copolovici DM, Langel K, Eriste E and Langel U: Cellpenetrating peptides: Design, synthesis, and applications. ACS Nano 8: 1972-1994, 2014. PMID: 24559246. DOI: 10.1021/ nn4057269

179 Thorén PE, Persson D, Isakson P, Goksör M, Onfelt A and Nordén B: Uptake of analogs of penetratin, Tat(48-60) and oligoarginine in live cells. Biochem Biophys Res Commun 307: 100-107, 2003. PMID: 12849987. DOI: 10.1016/s0006$291 \times(03) 01135-5$

180 Lam JK, Chow MY, Zhang Y and Leung SW: siRNA versus miRNA as therapeutics for gene silencing. Mol Ther Nucleic Acids 4: e252, 2015. PMID: 26372022. DOI: 10.1038/mtna.2015.23

181 Jones D: Setbacks shadow microRNA therapies in the clinic. Nat Biotechnol 36: 909-910, 2018. PMID: 30307922. DOI: 10.1038/nbt1018-909

182 Setten RL, Rossi JJ and Han SP: The current state and future directions of RNAi-based therapeutics. Nat Rev Drug Disc 18: 421-446, 2019. PMID: 30846871. DOI: 10.1038/s41573-0190017-4

183 Cormac S: Billion-dollar deal propels RNAi to CNS frontier. Nat Biotechnol 37: 699-706, 2019. PMID: 31267098. DOI: 10.1038/d41587-019-00014-7

Received June 16, 2020

Revised July 13, 2020

Accepted July 17, 2020 